\title{
Eosinophils in skin diseases
}

\section{Susanne Radonjic-Hoesli ${ }^{1}$. Marie-Charlotte Brüggen ${ }^{2,3,4}$ • Laurence Feldmeyer ${ }^{1}$. Hans-Uwe Simon ${ }^{5,6,7}$ (D) Dagmar Simon ${ }^{1}$ (D)}

Received: 27 April 2021 / Accepted: 6 May 2021 / Published online: 7 June 2021

(C) The Author(s) 2021

\begin{abstract}
Eosinophil infiltration is a common finding in a broad spectrum of skin diseases, despite the fact that the skin is devoid of eosinophils under physiologic conditions. Although cutaneous eosinophilia is reactive, cytokine-mediated in most cases, diseases with an intrinsic mutation-mediated clonal expansion of eosinophils can also manifest on the skin. As eosinophils are involved in host defense, regulate immune responses, generate pruritus, induce remodeling and fibrosis, and can cause tissue damage, they have the capacity to actively contribute to the pathogenesis of diseases. Recent research provided deeper insights in the mechanisms, e.g., bacterial and viral clearance, blister formation, recruitment of cytotoxic $\mathrm{T}$ cells, and generation of pruritus, by which eosinophils might come into action. This review aims at providing an overview on the clinical presentations of eosinophilassociated dermatoses and the current understanding of their pathogenic role in these diseases. Further, we discuss the effects of therapies targeting eosinophils.
\end{abstract}

Keywords Eosinophil · Granule proteins · Host defense · Immunoregulation · Tissue damage

\section{Introduction}

Eosinophil infiltration of the skin is a frequent histopathological finding in a broad spectrum of dermatological disorders. This observation might be astonishing considering the

$\overline{\text { Susanne Radonjic-Hoesli and Marie-Charlotte Brüggen equally contrib- }}$ uted to this review

This article is a contribution to the Special issue on: Eosinophils - Guest Editor: Hans-Uwe Simon

Dagmar Simon

dagmar.simon@insel.ch

1 Department of Dermatology, Inselspital, Bern University Hospital, University of Bern, Bern, Switzerland

2 Faculty of Medicine, University of Zurich, Zurich, Switzerland

3 Department of Dermatology, University Hospital Zurich, Zurich, Switzerland

4 Department of Dermatology, Hochgebirgsklinik Davos, Davos, Switzerland

5 Institute of Pharmacology, University of Bern, Bern, Switzerland

6 Department of Clinical Immunology and Allergology, Sechenov University, Moscow, Russia

7 Laboratory of Molecular Immunology, Institute of Fundamental Medicine and Biology, Kazan Federal University, Kazan, Russia fact that the skin does not harbor eosinophils under physiologic conditions. As eosinophilic dermatoses lack any specific clinical sign or pattern, a skin biopsy and histology together with the clinical manifestations are often required to get the correct diagnosis. Under the microscope, eosinophils easily attract attention as they appear as bright red granular cells in hematoxylin and eosin (H\&E) stained tissue. Indeed, the affinity to the red dye eosin was the reason why Paul Ehrlich named his newly discovered cells eosinophils [1,2]. Eosinophilic dermatoses present with or without accompanying peripheral blood eosinophilia, defined as absolute eosinophil counts $>0.5 \mathrm{G} / 1$ [3]. The development of targeted antieosinophil therapies that effectively deplete eosinophils in the blood and tissues has tremendously accelerated research on eosinophils in order to understand their function under physiologic and pathologic conditions. In the field of dermatology, progress has been made in demonstrating subgroups of eosinophils by their cytokine expression [4], different ways of mediator release [5], eosinophil-mediated effects on blister formation in bullous pemphigoid (BP) [6], vasopermeability [7], bacterial killing [8], and pruritus $[9,10]$, in elucidating eosinophil activation factors $[8,11]$, and roles in tumor biology $[12,13]$. Moreover, antibodies affecting eosinophils have been demonstrated to be effective in improving cutaneous manifestations of hypereosinophilic syndromes $[14,15]$. 
In this review, we are aiming at demonstrating the spectrum of eosinophilic diseases affecting the skin with special focus on the pathogenic roles of eosinophils and eosinophils as therapeutic targets.

\section{Eosinophils}

As innate immune cells, eosinophils are involved in host defense. They express several pattern recognition receptors, including toll-like receptors (TLR), nucleotide-binding oligomerization domain-like receptors (NLRs), G protein-coupled, Fc, chemokine, adhesion, and cytokine receptors [16, 17]. Receptor stimulation leads to degranulation of toxic granule proteins (eosinophil peroxidase (EPO), eosinophil cationic protein (ECP), eosinophil-derived neurotoxin (EDN), and major basic protein (MBP)), synthesis of nitric oxide, release of cytokines, and chemokines, and cell trafficking $[16,17]$.

\section{Toxic granule proteins}

Eosinophils are stuffed with granules, primary and secondary ones. Primary granules harbor Charcot-Leyden crystal (CLC) protein (galectin-10) and eosinophil peroxidase (EPO). A role of CLC has been associated with various eosinophilic including allergic and parasitic diseases. CLC is assumed to be involved in vesicular transport of cationic RNases and the granule formation during eosinophil differentiation [18]. EPO has been shown to exert antiparasitic and antibacterial effects. It is released either into large cytoplasmic vacuoles (phagosomes) or extracellularly where it binds to the surface of a target [18].

Secondary granules contain major basic protein (MBP) in the crystalline core, as well as eosinophil cationic protein (ECP), eosinophil-derived neurotoxin (EDN), and EPO in their matrix. ECP was shown to directly damage schistosomula of Schistosoma mansoni [19]. ECP, EDN and MBP have antibacterial properties that are dependent or independent of RNase activity [20-22]. Eosinophil-derived neurotoxin (EDN) is a member of the RNase superfamily. In addition to its ribonuclease activity resulting in neurotoxic and antiviral effects, EDN serves as a chemoattractant of dendritic cells, and as an endogenous ligand for toll-like receptor (TLR)2 [23]. ECP, MBP, and EPO have been identified as major components of eosinophil extracellular traps (EET) [5, 24]. To note, in the process of EET formation, degranulation and mitochondrial DNA release occur sequentially, suggesting that the DNA scaffold and granule proteins associate in the extracellular space [25]. In the granules, MBP is stored as nanocrystals that are nontoxic [26]. Its toxicity is triggered by granule acidification upon stimulation of eosinophils and extracellular aggregation [26]. Interestingly, further aggregation of MBP results in large amyloid plaques that are nontoxic and most likely limit tissue damage. Such MBP+ amyloid plaques have been observed in biopsies from eosinophilic cellulitis and atopic dermatitis (AD) [26].

\section{Mediator release}

Eosinophil function is dependent on the release of toxic granule proteins, cytokines, and chemokines (Fig. 1). These mediators are mostly stored within the secondary granules of eosinophils [27]. Different modes of degranulation exist, determining the execution of eosinophil function. In piecemeal degranulation, the most abundant form of degranulation found in tissue sections, eosinophils are capable of selectively secreting granule contents depending on the stimulus. For example, stimulation of eosinophils with RANTES or eotaxin-1 results in secretion of interleukin (IL)-4, whereas upon interferon (INF)- $\gamma$ stimulation, eosinophils secrete IL-12 but not IL-4 [28]. On an ultrastructural level, piecemeal degranulation is characterized by a loss of density of secondary granules and the presence of so-called sombrero vesicles, corresponding to tubular structures serving as secretory vesicles, finally fusing with the plasma membrane for mediator release [28]. Classical exocytosis has been observed in close proximity to large parasites [29].

Eosinophil cytolysis, the second most common form of granule protein release into tissues, is the result of utmost activation of the eosinophil that results in cell death. On an ultrastructural level, chromatolysis and loss of plasma membrane integrity are found, alongside with deposits of so-called clusters of free eosinophil granules (cfegs). Interestingly, these partially intact cell-free granules appear to maintain effector

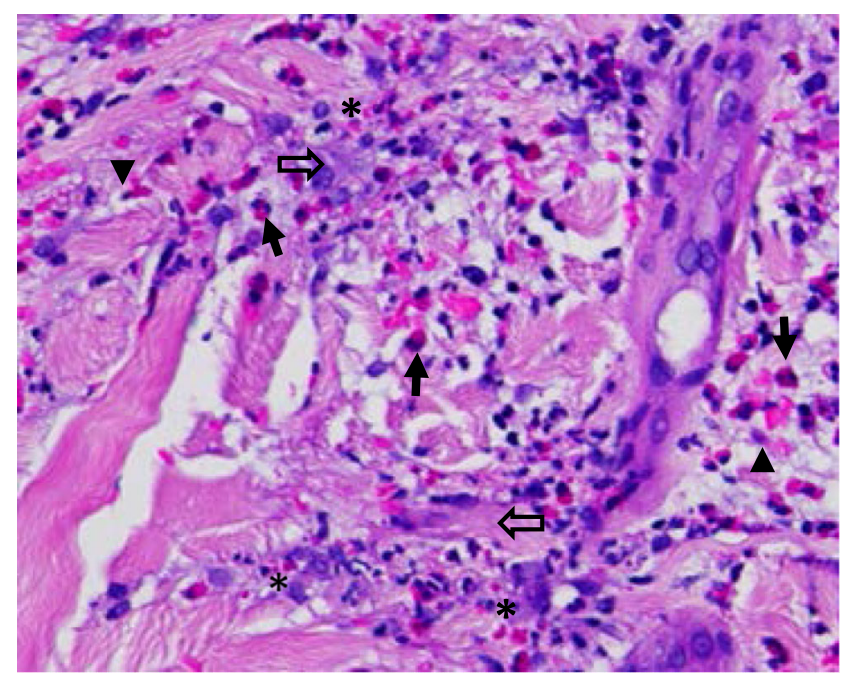

Fig. 1 Eosinophil infiltration in the skin. The image shows round shaped eosinophils with their typical bi-lobed nuclei (arrow), cell-free granules indicating degranulation (*), cytolytic eosinophils (arrowhead), and flame figures presenting necrobiotic collagen fibres covered by eosinophil granule proteins (open arrow). Magnification $\times 400$ 
function. Stimulation of cfegs with IL-4, RANTES or IFN- $\gamma$ resulted in stimulus-dependent mediator release [30, 31]. Recently, adhesion-induced cytolysis was characterized as a nonapoptotic form of cell death with features of necroptosis, counter-regulated by autophagy [32]. Cytolysis-associated morphologic changes of eosinophils such as cytoplasmic vacuolization have been observed in various dermatoses [32].

Catapult-like release of mitochondrial DNA that associates with eosinophil granule proteins, resulting in the formation of net-like structures, is referred to as EET formation [24]. Extracellular traps are formed by viable cells, therefore, cell death, including eosinophil cytolysis, is not required [33]. Through EET formation, eosinophils are able to bind and kill extracellular bacteria [8]. EETs have been detected in a variety of skin disorders, including infectious, but also allergic and autoimmune diseases [5, 34].

\section{Cytokines expression by eosinophils}

By the production and release of cytokines and chemokines, eosinophils function as immunomodulatory cells. They are often associated with type 2 inflammation as they respond to IL-5 and secrete cytokine such as IL-4, IL-9, and IL-13 that may affect Th2 cells, B cells, and macrophages [17]. By releasing GM-CSF, IL-8, and IL-10, eosinophils have the potential of attracting neutrophils, autostimulation, and immunoregulation [17]. Via synthesis of tumor necrosis factor (TNF)- $\alpha$, eosinophils may exert cytotoxic effects [35]. To note, eosinophils are a source of IL-31, a cytokine that bridges inflammation and pruritus [9]. There is evidence that, with respect to cytokine production, distinct subpopulations of eosinophils exist in the skin depending on the underlying disease and inflammatory milieu [4].

\section{Fibrosis}

Eosinophils have been reported to express CCL11 (eotaxin-1), tumor growth factor (TGF)- $\beta$, IL-6, IL-11, IL-13, and MMP-9 and thus may directly or indirectly stimulate tissue remodeling or fibrosis. A correlation of tissue eosinophils and mediator release with deposition of extracellular matrix proteins has been shown in skin diseases [4], eosinophilic esophagitis [36], and asthma [37]. TGF- $\beta$, which can either be released by eosinophils or by epithelial cells upon stimulation with IL4 and IL-13, was shown to activate fibroblasts resulting in the secretion of matrix proteins, as well as the release of eotaxin stimulating an additional recruitment of eosinophils [38].CCL11 has profibrogenic properties on fibroblasts expressing its receptor CCR-3 [39]. In mouse models, IL-11 that is produced by eosinophils and structural cells, was shown to stimulate fibrosis [40].
Potential roles of eosinophils in skin diseases

For most eosinophilic dermatoses, the exact pathogenic mechanism, specifically the role of eosinophils is still obscure. Here, we will discuss some general mechanisms together with the possible contribution of eosinophils.

\section{Host defense}

Eosinophils are assumed to be involved in killing helminths particularly those in tissue-migratory stages by releasing toxic granule proteins and reactive oxygen species, as well as mediating protection against reinfection [41]. Notably, released eosinophil granule proteins cause concomitant tissue damage contributing to the disease pathology [41]. Antibacterial effects by eosinophils have been attributed to toxic effects of MBP and eosinophil cationic protein (ECP), the phagocytic capacity of eosinophils, although this is much less compared to neutrophils, and the formation of EETs [24]. Eosinophils have also been shown to promote virus clearance by releasing EDN, an RNase, that reduces virus infectivity, as well as activates dendritic cells by interacting with TLR2 resulting in IL- 6 and TNF- $\alpha$ release, and functions as chemoattractant for macrophages [42]. Furthermore, eosinophils may function as antigen-presenting cells and stimulate CD8+ cells [43].

\section{Edema and blister formation}

Eosinophils may contribute to edema by releasing eosinophil granule proteins, as well as by the production of leukotrienes that have direct vasodilatory effects on blood vessels or indirectly via stimulation of mast cells and basophils [44, 45]. Eosinophil infiltration in the skin and lining along the dermal-epidermal junction are observed in bullous pemphigoid (BP), an autoimmune-bullous disease. In the presence of BP autoantibodies eosinophils upon activation by IL-5 were shown to directly contribute to blister formation using an ex vivo skin model [6]. Adhesion, Fc $\gamma$ receptor activation, elevated ROS production, and EET formation by eosinophils have been shown to be involved in dermal-epidermal separation [6]. Furthermore, ECP and EDN have been reported to exert cytotoxic effects on keratinocytes and cause cell-matrix detachment [46].

\section{Recruitment and activation of cytotoxic $\mathbf{T}$ cells}

Through the recruitment and activation of cytotoxic $\mathrm{T}$ cells and natural killer (NK) cells, eosinophils have been demonstrated to restrict tumor growth [47-49], defend viral infection [43], and, likely, are involved in drug rash with eosinophilia and systemic symptoms (DRESS) [50]. 


\section{Induction of pruritus}

Most eosinophilic dermatoses are associated with pruritus that can be incredible, e.g., in atopic dermatitis, prurigo nodularis and scabies. Eosinophils may stimulate nerve cells and contribute to pruritus by releasing granule proteins (ECP, EDN, $\mathrm{MCP}$ ), mediators such as substance $\mathrm{P}$, vasoactive intestinal peptide, brain-derived neurotrophic factor, neurotrophin-3, nerve growth factor, and cytokines such as IL-4, IL-13, and IL-31 [51]. A key role of IL-31 in causing itch has been demonstrated for atopic dermatitis, prurigo nodularis, dermatomyositis, and, with a direct contribution of eosinophils, for BP [10, 52-54]. In cutaneous T cell lymphoma (CTCL), eosinophil infiltration correlates with itch severity [55].

\section{Primary and secondary causes of eosinophilia}

Since the clinical presentation of eosinophilic dermatoses is manifold and usually lacks specific criteria, a skin biopsy is indispensable to establish the correct diagnosis by histological, immunohistological and molecular analyses that should be complemented by blood tests and, if required, imaging. The accumulation of eosinophils in the skin and/or blood and other organs can be caused by either a mutation or gene fusion-mediated clonal expansion of eosinophils or a cytokine-mediated increased differentiation and survival of eosinophils. Intrinsic (clonal, neoplastic) eosinophilia is due to genetic changes in hematopoietic stem cells leading to chronic myeloid leukemias with eosinophils as part of the clonally expanded cells. Extrinsic, reactive forms of eosinophilia are the most common ones caused by cytokines such as IL-3, IL-5, and GM-CSF that are released by mainly T cells, as well as tumor cells $[3,56]$. Determining the cause of eosinophilia has immense implications on the therapy of the underlying disease [57-59].

\section{Clinical patterns of eosinophilic dermatoses}

Next, we will present the spectrum of eosinophilic dermatoses based on their clinical presentations (Fig. 2) and provide current knowledge on the pathogenesis with special focus on a role of eosinophils.

\section{Eczematous pattern}

Atopic dermatitis is a common chronic inflammatory skin disease with a prevalence of up to $20 \%$ in children and $8 \%$ in adults [60]. It presents with highly pruritic eczematous skin lesions affecting the face, neck, and extensor sites of the extremities in infants, as well as chronically inflamed lesions with lichenification of the flexural folds in adults (Fig. 3A).
The pathogenesis is based on a genetic predisposition that determines both skin barrier dysfunction and predominant type 2 inflammation, as well as environmental factors [60]. Owing to the impaired skin barrier, the skin microbiome is altered resulting in a colonization of Staphylococcus aureus that further harm the barrier, the susceptibility to viral infection is increased, and environmental allergens may enter in the skin. In consequence, innate and adaptive immune responses are activated. Tissue eosinophilia that has been observed in both acute and chronic AD lesions, is often accompanied by elevated blood eosinophil levels correlating with disease severity $[61,62]$. In addition to intact eosinophils, cytolytic eosinophils, extracellular granules, and eosinophil toxic protein deposits have been found in AD skin [26, 61, 63, 64]. Thymic stromal lymphopoietin (TSLP) that is highly expressed by keratinocytes in $\mathrm{AD}$ was shown to stimulate EET formation [8]. EETs were detectable in atopy patch test reactions as model of an acute AD flare [5]. Eosinophils express type 2 cytokines and thus may actively contribute to AD inflammation. Pruritus can be stimulated by eosinophils as they release toxic granule proteins, neuromediators, and cytokines, in particular IL-31 [51]. Blocking the IL-31 receptor results in a rapid and significant reduction of pruritus followed by an improvement of $\mathrm{AD}$ severity [65]. As in allergic/reactive skin diseases, eosinophils express IL-11, IL-13, TGF- $\beta$, and CCL11, they would be able to induce fibrosis [4]. Thus, the following roles of eosinophils in the pathogenesis of $\mathrm{AD}$ can be hypothesized: defending invading pathogens by toxic granule proteins and EETs, stimulating inflammation, contributing to fibrosis, and initiating pruritus. In patients with $\mathrm{AD}$, blocking IL-5 with mepolizumab had only slight effects on disease severity [66, 67]. Although mepolizumab significantly reduced blood eosinophils, it remains unclear whether it sufficiently affected eosinophil infiltration and activation in lesional AD skin.

Contact dermatitis, both allergic (ACD) and irritant (ICD), presents with acute and/or chronic eczematous lesions triggered by contact allergens and irritants, respectively. Whereas in ICD the innate immune system is activated, in ACD both innate and adaptive, mainly type 1, immune responses are involved. In both ICD and ACD, skin barrier disruption followed by a proinflammatory cytokine milieu and inflammation play an important pathogenic role [68]. Among skin infiltrating cells, few eosinophils are present. Eosinophils generating EETs have been detected in ACD [5]. Moreover, eosinophils that constitutively bear the $1 \mathrm{~L}-17$ receptor together with Th17 cells are present in eczematous skin lesions. The number of Th17 cells correlated with that of MMP-9+ eosinophils, as well as tenascin deposition [69]. These observations suggest a role of eosinophils in pathogen defense and in remodeling.

Worldwide, parasitic infections are the most frequent causes of secondary eosinophilia. Scabies and larva migrans 
Fig. 2 Clinical patterns of skin diseases with eosinophilia and examples
Skin diseases with eosinophilia

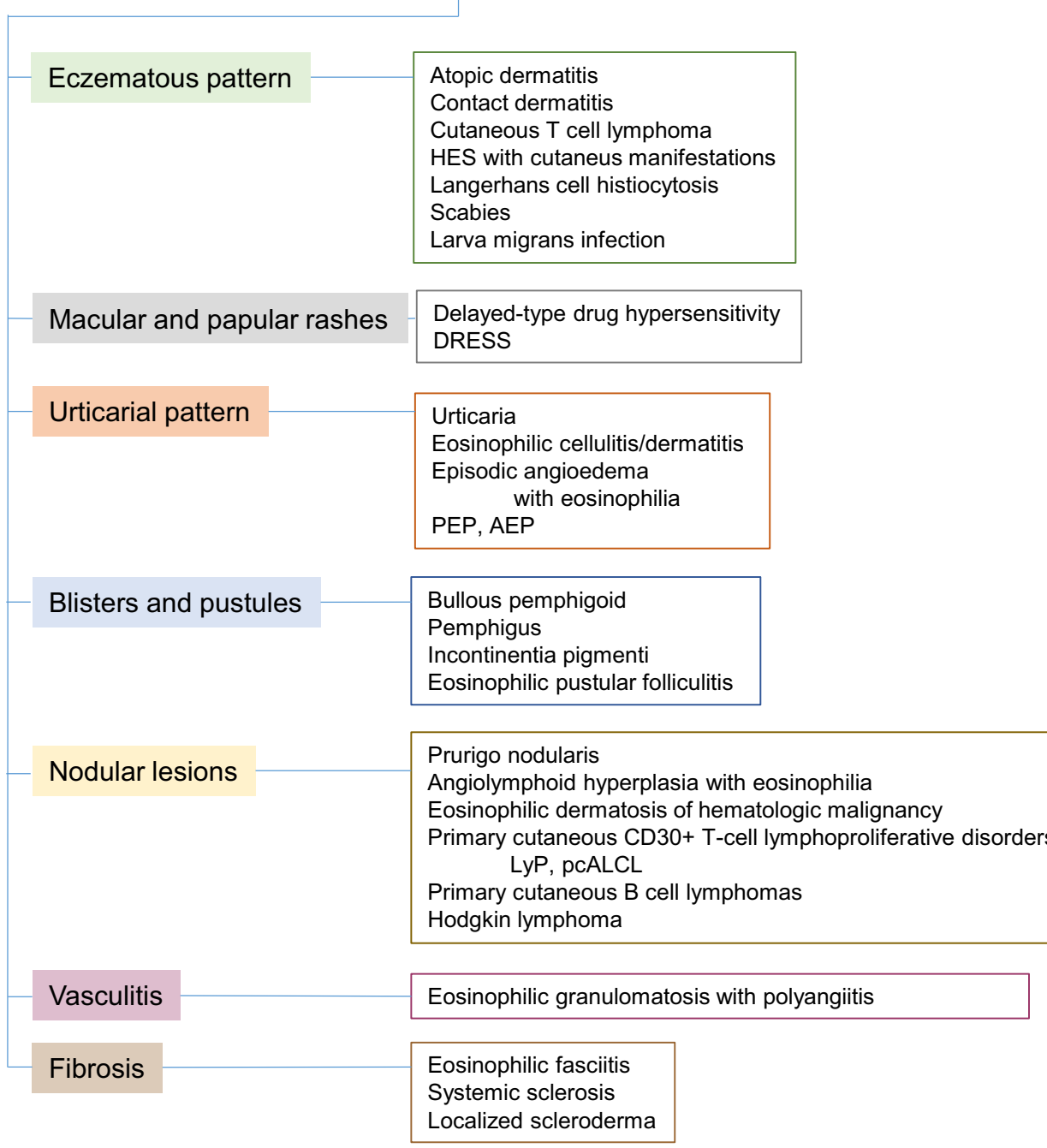

$A E P$, atopic eruption of pregnancy; DRESS, drug rash with eosinophilia and systemic symptoms; HES, hypereosinophilic syndromes; LyP, Iymphomatoid papulosis; pcALCLPEP, primary cutaneous anaplastic large cell lymphoma; PEP, polymorphic eruption of pregnancy. infection are common diseases. The skin infected by the scabies mite Sarcoptes scabiei presents with papules and linear burrows (Fig. 3A). It is infiltrated by mainly eosinophils, T cells, monocytes, macrophages, and mast cells, resembling a chronic allergic reaction [70]. Eosinophils have been demonstrated to generate EETs and release toxic granule proteins in both scabies and larva migrans skin lesions and thus would have the capacity to contribute to clearing of pathogens [5]. Epithelial barrier defects and epidermal proliferation similar to those in AD and psoriasis have been observed in scabies [70]. Eosinophils release cytokines and thus may stimulate adaptive, e.g., Th1, Th2, Th17, and regulatory T cells; immune responses that can be either pro- or antiinflammatory [70]. It is likely, that eosinophils contribute to bullous scabies reported in several case reports [71]. Moreover, the intense pruritus associated with scabies and larva migrans infection might be promoted by eosinophils [10].

Epidermotropic forms of cutaneous $T$ cell lymphoma (CTCL) are characterized by the infiltration of malignant, clonally expanded T cells [72]. The malignant cells resemble central memory $\mathrm{T}$ cells in Sezary syndrome (SS), and effector memory $\mathrm{T}$ cells in mycosis fungoides (MF) [73]. Erythroderma, severe pruritus, atypical $\mathrm{T}$ cells in the peripheral blood and lymphadenopathy are typical signs of SS. MF presents with highly pruritic erythematous patches, plaques, and tumors on the skin (Fig. 3A) [74]. MF and SS have been associated with a Th 2 cytokine milieu including elevated IL-5 expression leading to eosinophilia in skin 


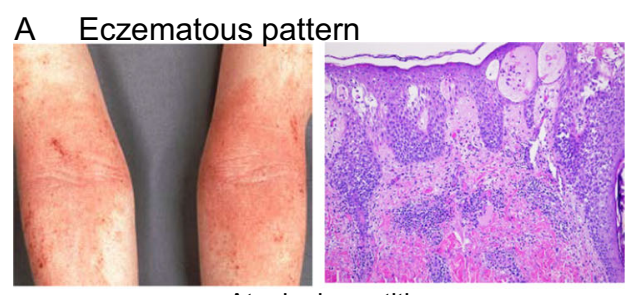

Atopic dermatitis

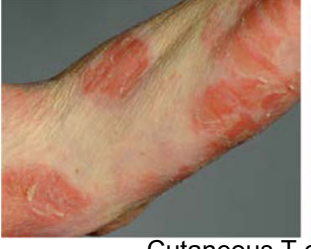

Cutaneous T cell lymphoma

\section{Urticarial pattern}

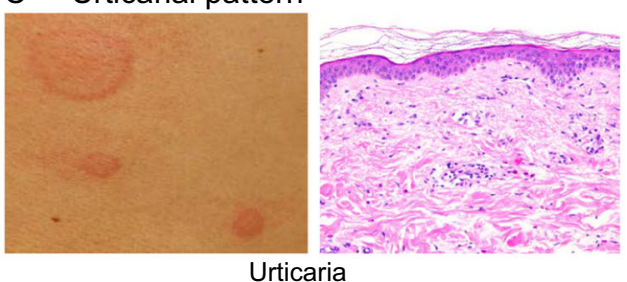

D Blisters and pustules

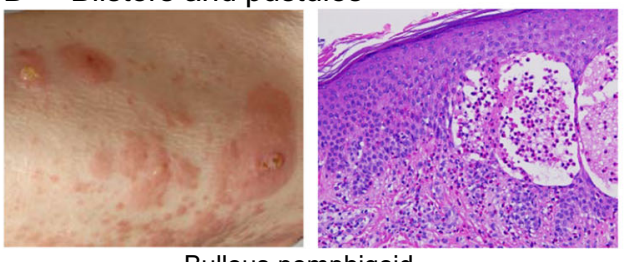

Bullous pemphigoid

\section{E Nodular lesions}

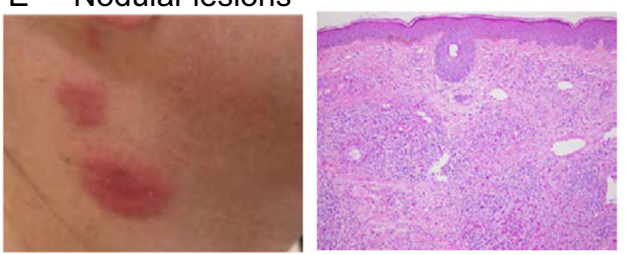

Granuloma faciale

\section{F Vasculitis}

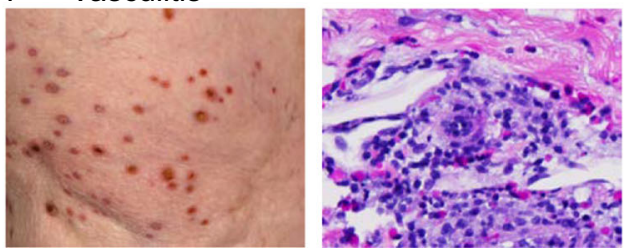

Eosinophilic granulomatosis with polyangiitis

and peripheral blood [75]. Interestingly, blood eosinophilia was associated with disease progression and diseasespecific death [76].

Cutaneous manifestations are the most common organ manifestations in patients with hypereosinophilia [77]. In

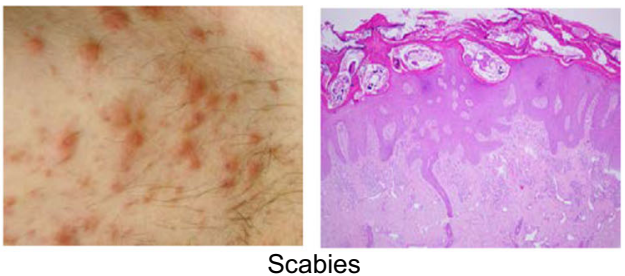

\section{B Macular and papular rash}

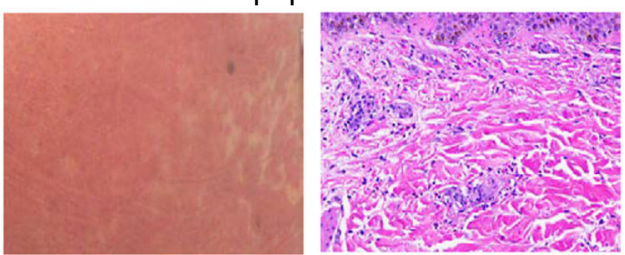

Drug rash with eosinophilia and systemic symptoms
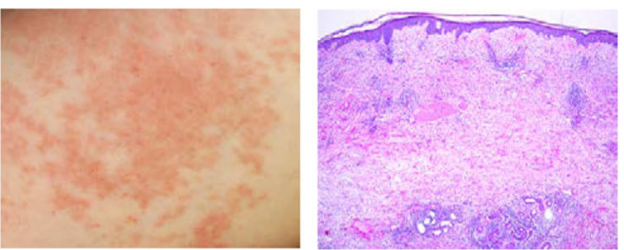

Eosinophilic dermatitis (Wells syndrom)

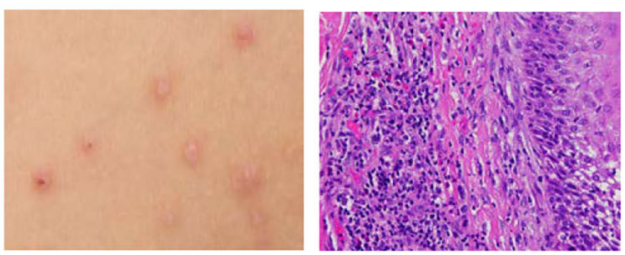

Eosinophilic pustular folliculitis
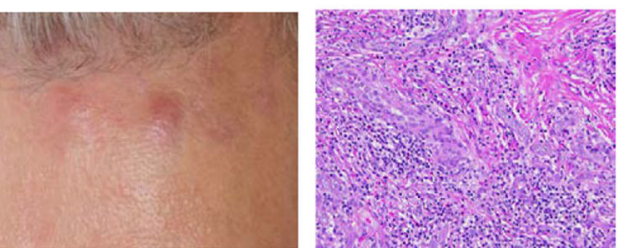

Angiolymphoid hyperplasia with eosinophilia

\section{G Fibrosis}

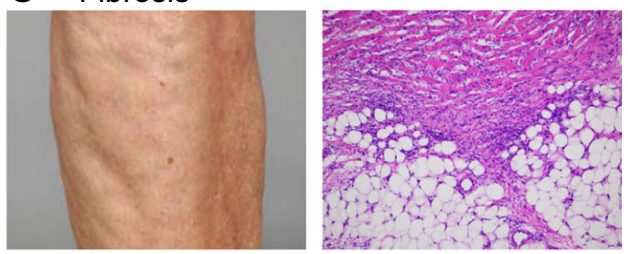

Eosinophilic fasciitis

patients with hypereosinophilia due to T cells with an aberrant immunophenotype, defined as lymphocytic variant of HES (L-HES), a broad spectrum of pruritic skin lesions including erythroderma, erythematous papules, urticarial plaques, and poikiloderma can be observed [78, 79]. On histology, 
Fig. 3 Clinical and histological presentations of dermatoses associated with eosinophilia. Images demonstrate typical skin lesions and pathological findings in $\mathrm{H} \& \mathrm{E}$ stained skin specimens of selected dermatoses with eczematous pattern (A), macular and papular rashes (B), urticarial pattern (C), blister and pustules (D), nodular lesions (E), vasculitis $(\mathbf{F})$, and fibrosis $(\mathbf{G})$.

The key clinical and histopathological cutaneous features are the following: (A) Atopic dermatitis: eczema in flexural folds, spongiosis, acanthosis, superficial perivascular lymphohistiocytic infiltrate with eosinophils; scabies: linear burrows, eosinophils are main infiltrating cells; cutaneous $\mathrm{T}$ cell lymphoma: eczematous lesions, lymphocytic infiltrate with epidermotropism, occasional eosinophils in dermis; (B) DRESS: widespread erythematous macules and papules, facial edema, unspecific histology, perivascular lymphohistiocytic infiltrate with eosinophils; (C) urticaria: wheals, dermal edema and discrete mixed infiltrate with few eosinophils; eosinophilic cellulitis/dermatitis: urticarial patches; interstitial eosinophil infiltrate, flame figures; (D) bullous pemphigoid: blisters in urticarial or eczematous lesions, subepidermal blisters, numerous eosinophils in the dermis, lining at the dermal-epidermal junction and in blisters; eosinophilic pustular folliculitis: disseminated sterile pustules, intra- and perifollicular eosinophil-rich infiltrate; (E) granuloma faciale: brownish-red nodules and plaques; mixed, eosinophil-rich infiltrates with a grenz zone; angiolymphoid hyperplasia with eosinophilia: grouped violaceous to brownish papules and nodules, proliferation of blood vessels with epitheloid endothelial cell proliferation with cytoplasmic vacuoles, diffuse infiltrate of lymphocytes and numerous eosinophils; (F) esinophilic granulomatosis and polyangiitis: purpuric nodules, intraand perivascular infiltrate of lymphocytes and eosinophils, destruction of vessel wall, fibrinoid deposition; $(\mathbf{G})$ eosinophilic fasciitis: plate-like hardness of distal limbs, groove sign of blood vessels, thickening of fascia, infiltrate of lymphocytes, plasma cells and eosinophils in early stages

perivascular infiltrates with lymphocytes and eosinophils with various degrees of epidermal involvement are evident [79]. The increased production of eosinophils and accumulation in the skin is due to the production of IL-5 and/or IL-3 by aberrant T cells $[78,79]$. Patients with L-HES and cutaneous involvement respond usually well to anti-IL-5 and anti-IL-5 receptor therapy $[14,15]$.

Langerhans cell (LHC) histiocytosis may occur at any age but primarily affects children. The skin lesions often present with erythematous scaly or crusted papules and patches resembling seborrheic eczema. In addition, pustules, vesicles, petechiae, and purpura, as well as localized yellowish plaques and macules, are observed [80]. The infiltrate in the papillary dermis and epidermis harbors CD1a- and CD207-positive LHC and numerus eosinophils [80]. Cytokines that may directly affect eosinophils, are produced by either LHC, e.g., GM-CSF, IL-10, IFN- $\gamma$, or T cells and macrophages, e.g., IL-3, IL-2, IL-4, IL-5, and TNF- $\alpha[81,82]$.

\section{Macular and papular rashes}

Delayed-type drug hypersensitivity reactions (DDH) are considered to be mainly $\mathrm{T}$ cell mediated immune responses [83]. Eosinophils are commonly found both in the blood and, to a smaller extent, in lesional skin of patients with DDH [84]. Despite this finding, surprisingly little is known about the pathophysiological role of eosinophils in DDH.

Most DDH have a benign disease course such as maculopapular drug eruptions [84]. Other, rare benign DDH are the fixed drug eruption and the symmetrical drug-related intertriginous and flexural exanthema (SDRIFE). Severe DDH are rare, but potentially life-threatening. They include acute general exanthematous pustulosis (AGEP), the hallmark of which are nonfollicular pustules on an erythematous ground and concurrent systemic involvement in about $20 \%$ of cases [85], Stevens-Johnsons syndrome and toxic epidermal necrolysis that are characterized by epidermal detachment and potential mucosal involvement, and drug rash with eosinophilia and systemic symptoms (DRESS), an eosinophilpredominated reaction [86].

DRESS, also known as drug-induced hypersensitivity syndrome, has an estimated incidence of 10 cases per million per year [86]. The diagnosis of DRESS is based on a combination of clinical symptoms and laboratory parameters (Table 1) [87, 88]. Cutaneous signs are rather nonspecific: a maculopapular rash is the most common presentation, but urticarial lesions and mucosal involvement have also been reported $[86,87,89]$ (Fig. 3B). Additional signs of DRESS include facial edema, enlarged lymph nodes and fever, as well as positive serology for viruses such as human herpes virus 6 (HHV6) and Epstein-Barr virus (EBV) [90]. These features are paralleled by a dysfunction of potentially any organ (Table 1). The liver is most commonly affected (ca. $75 \%$ of the cases), followed by kidneys and lungs (ca. 35\%) [90,91]. The mortality rate of DRESS is $5-10 \%$ [92]. There is no pathognomonic histopathology of DRESS, but interface dermatitis is the most common finding $[50,93]$. While blood eosinophilia is a key feature of DRESS and present in the vast majority of patients, cutaneous eosinophil infiltration and the presence of atypical lymphocytes have been reported less frequently [50, 89].

In DRESS, T cells recognizing drug-derived haptens expand, a process that can be associated with reactivation of certain viruses such as HHV6, herpes virus 1, EBV and cytomegalovirus [88]. IL-5 is considered the main driver of eosinophil expansion and activation leading to organ damage and dysfunction in DRESS [94]. The efficacy of antibodies targeting the IL-5 / IL-5 receptor axis in severe DRESS are an evidence for the key role of eosinophils in the pathogenesis [95-97].

\section{Urticarial pattern}

In urticaria that presents with wheals, angioedema or both, mast cells are the key drivers [98]. The acute form, clearing within 6 weeks, is very common and mainly associated with infections of the upper respiratory tract, drugs, and IgE- 
Table 1 Diagnostic criteria of DRESS (RegiSCAR) [87]

\begin{tabular}{llll}
\hline Criteria & No & Yes & Unknown \\
\hline Fever $>38.5^{\circ} \mathrm{C}$ & -1 & 0 & -1 \\
Lymphadenopathy & 0 & 1 & 0 \\
Skin rash $>50 \%$ body surface & 0 & 1 & \\
Edema, infiltration, scaling & -1 & 1 \\
Resolution in $>15$ days & -1 & 0 & -1 \\
Atypical lymphocytes & 0 & 1 & 0 \\
Blood eosinophilia & 0 & 1 & \\
$10-19.9 \%$ or $700-1499$ Gpt/l & & 2 & \\
$>20 \%$ or $>1500$ Gpt/1 & & & \\
Evaluation of other potential causes & 0 & 1 & 0 \\
(antinuclear antibodies, blood culture, hepatitis A, B, C serology, & & & \\
\multicolumn{1}{c|}{ chlamydia/mycoplasma) } & & & \\
\hline
\end{tabular}

*Heart, liver, kidney, muscle, pancreas or other

Scores 1-3: diagnosis uncertain; score 4 or higher: diagnosis certain mediated allergies. Physical stimuli such as heat, cold, vibration, and UV light are among the triggers of chronic inducible urticaria. In a subgroup of patients with chronic spontaneous urticaria (CSU), autoimmune responses have been identified as relevant pathogenic mechanisms [98]. Eosinophils are found among the mixed inflammatory infiltrate in the dermis (Fig. 3C). Since eosinophils express tissue factor and VEGF, as well as leukotrienes, they may increase vascular permeability resulting in dermal edema and wheal formation [99-101]. A recent review pointed to eosinophil-mast cell interaction: eosinophils may directly stimulate mast cells via the release of toxic granule proteins provoking degranulation and stem cell factor [101]. Interestingly, blood eosinopenia is associated with higher disease activity and poor response to treatment in CSU patients, in particular those with type IIb autoimmune CSU [102].

Eosinophilic cellulitis/dermatitis (EC), also referred to as Wells' syndrome, is a rare dermatological condition characterized by persistent urticarial plaques and sometimes blister formation, as well as an eosinophil infiltrate in the dermis (Fig. 3C) [103]. Blood eosinophilia may be present. EC has been considered an organ restricted eosinophilic disorder among hypereosinophilic syndromes [104]. An increased expression of IL-5 has been detected in both tissue and blood [105]. Both eosinophils scattered throughout the dermis and extracellular eosinophil granules have been observed $[4,5]$. EET formation is prominent and accentuated in eosinophil clusters, where up to $50 \%$ of eosinophils generate EETs [5]. A typical, but not pathognomonic finding is the presence of flame figures that correspond to amorphous collagen fibers covered by eosinophil granule proteins suggesting a pathogenic role of toxic granule proteins $[5,106]$. Recently, an expression of CD25, the alpha-chain of the IL-2 receptor, on blood and tissue eosinophils of patients with EC that is mediated by high IL-5 expression, was demonstrated. Thus, IL-2 can act as potent priming factor, resulting in a strong ECP release upon additional stimulation with platelet activating factor [11].

Recent data emphasize high effectiveness of mepolizumab, an anti-IL-5-antibody, in the treatment of EC [107].

Episodic angioedema with eosinophilia (EAE), first described by Gleich et al. 1984, is a rare episodic variant of hypereosinophilic syndromes. It presents with recurrent attacks of angioedema, urticaria, transient weight gain, fever, and elevated leukocyte counts [108]. Abnormal CD3- CD4+ $\mathrm{T}$ cells have been detected in patients with EAE [109, 110]. Interestingly, a cycling of eosinophils together with other cell lineages including neutrophils and lymphocytes has been observed [109]. In addition to corticosteroids, mepolizumab and imatinib have successfully been applied in patients with EAE [111, 112].

Among specific dermatoses of pregnancy, polymorphic eruption of pregnancy (PEP) and atopic eruption of pregnancy (AEP) are the most frequent ones. They are associated with intense pruritus [113]. Clinically, AEP patients present with eczematous lesions and/or prurigo nodules starting in the second or third trimester. PEP typically affects primigravidae showing pruritic urticarial papules and plaques [113]. The histopathological analysis of skin specimens revealed the presence of eosinophils in 14/19 cases of AEP and in all 22 cases of PEP [113].

\section{Blisters and pustules}

Bullous pemphigoid is the most common autoimmune bullous skin disease affecting mainly the elderly. It is characterized by an autoimmune response against hemidesmosomal antigens, involving autoreactive $\mathrm{T}$ and $\mathrm{B}$ cells. BP presents with urticarial and eczematous lesions, as well as in general blisters. Eosinophils infiltrating the skin are a striking histopathological finding. They are located in the dermis, where they often 
line along the dermal-epidermal junction, and in blisters (Fig. 3D). Cytokines known to recruit and activate eosinophils such as IL-5 and eotaxin are expressed in lesional skin [114, 115]. In the presence of BP antibodies, IL-5-activated eosinophils have been demonstrated to cause splitting at the dermalepidermal junction in an ex vivo skin model [6]. BP is associated with severe pruritus. Elevated IL-31 serum levels correlating with numbers of eosinophil, which are a source of IL31 , have been found in BP patients $[10,116]$. In a clinical trial, the anti-IL-5 antibody mepolizumab failed to significantly improve BP [117]. The lack of efficacy could be explained by an insufficient reduction of tissue eosinophils [117].

The pemphigus group is characterized by acantholysis of keratinocytes due to antidesmoglein and antidesmocolin antibodies resulting in blisters and erosions. Pemphigus vegetans has been associated with eosinophil infiltration in the skin, specifically eosinophil exocytosis and eosinophilic abscesses, as well as elevated blood eosinophil and ECP levels [118]. However, the role of eosinophils in terms of epidermal disintegration or hyperproliferation remains unclear.

Incontinentia pigmenti (IP) is caused by mutations of an Xlinked regulatory gene, termed nuclear factor-kappa $\mathrm{B}$ (NF-KB) essential modulator (NEMO). The combination of eosinophilic spongiosis, vesiculation, and dyskeratotic keratinocytes is a distinct feature of IP [119]. In the initial, vesiculo-bullous stage, the epidermis expresses eotaxin correlating with the accumulation of eosinophils [120]. To note, the eotaxin promoter has an NF-KB binding site [121].

Eosinophilic pustular folliculitis (EPF) is an inflammatory skin conditions, typically presenting with sterile follicular papulopustules (Fig. 3D). Three different subtypes have been described so far, classical (Ofuji disease), immunodeficiencyassociated and EPF of infancy. The prompt therapeutic response to indomethacin is pathognomonic. The histology shows an accumulation of eosinophils in the pilosebaceous unit. Recently, an increased expression of prostaglandin D synthetase by inflammatory cells including eosinophils has been demonstrated around the pilosebaceous unit [122]. Prostaglandin D2 induces mRNA expression of eotaxin-3 (CCL26), a potent chemoattractant for eosinophils, by human sebocytes in a dose-dependent manner. These findings might explain both the inflammatory pattern, as well as the therapeutic effect of indomethacin [122]. In addition, increased expression of TNF- $\alpha$ by tissue eosinophils has been found in EPF [4]. A pathogenic role of eosinophils is underlined by the fact that the anti-IL-5 receptor antibody benralizumab is effective in EPF [123].

\section{Nodular lesions}

Prurigo nodularis stands for a clinical reaction pattern induced by chronic pruritus and permanent scratching presenting with symmetrically distributed, firm, hyperkeratotic, excoriated nodules [124]. On histology, few eosinophils have been detected in all specimens investigated, and extracellular deposition of the eosinophil granule proteins were found in most of them [125]. As eosinophils produce an armory of toxic proteins, cytokines and mediators that can activate nerve cells, they are predisposed to contribute to pruritus [126].

Solitary asymptomatic brown-red to livid papules, nodules or plaques on the face are the typical clinical manifestation of granuloma faciale (EF). Histologically, it is characterized by a mixed cellular infiltrate, composed of lymphocytes, neutrophils, and eosinophils (Fig. 3E). An infiltrate-free grenz zone in the papillary dermis is pathognomonic. Recently, a clonal expansion of skin-homing CD4+ T cells has been demonstrated alongside with an increase in local IL-5 expression [127]. Increased IL-5 expression is associated with both increased eosinophil recruitment, survival, and activation. The role of the eosinophil itself in the pathogenesis of granuloma faciale has not been determined yet. Recently, an EF sharing features with an IgG4-associated sclerosing disease has been reported [128].

Angiolymphoid hyperplasia with eosinophilia (ALHE) is a benign vascular neoplasia with an eosinophil-rich infiltrate, presenting as livid papule or plaque on the face. Kimura disease is defined by deep subcutaneous swellings, the presence of blood eosinophilia, increased levels of total IgE alongside with a lymphadenopathy [129]. Currently Kimura disease and ALHE are considered as spectrum of the same disease. The infiltrate is composed of T cells, B cells, eosinophils, and plasma cells (Fig. 3E).

In ALHE lesions, eosinophils show a strong expression of IL-13 and TGF- $\beta$, as well as CCL24 and MMP-9, pointing toward a role of the eosinophil in immunoregulation and tissue remodeling [4]. Mast cells and eosinophils in close proximity, as well as T cells, can be found in Kimura disease [130]. As mast cells and eosinophils produce IL-5, CCR3 and RANTES, a bidirectional interaction of eosinophils und mast cells can be assumed [130, 131].

Eosinophilic dermatosis of hematologic malignancy (EDHM), previously also referred to as exaggerated insect bite-like reaction, is mainly associated with chronic lymphatic leukemia [132]. Clinically, it presents with pruritic papules and occasionally bullae. Based on a clinical and immunohistochemical study of six EDHM cases, Th 2 cells reactive to malignant B cells by producing IL-5 have been suggested to be responsible for eosinophil accumulation and activation, and subsequent clinical signs and symptoms [133]. There is evidence that neoplastic B cells are part of the infiltrate in EDHM lesions [134].

Eosinophil infiltration is observed in various cutaneous lymphomas. Primary cutaneous CD30+ T-cell lymphoproliferative disorders include lymphomatoid papulosis (LyP) and anaplastic large cell lymphoma (pcALCL) that manifest with papules, plaques, and nodules [135]. Patients with LyP that is self- 
healing, have an increased risk of developing secondary lymphoproliferative disorders such as a CD30+ ALCL, Hodgkin lymphoma or mycosis fungoides [135]. The presence of eosinophils in skin lesions is due to IL-3, IL-5, or GM-CSF expression by the malignant $T$ cells [136]. In primary cutaneous $B$ cell lymphomas, an aberrant expression of the $\mathrm{B}$ cell lymphoma (BCL)-6 transcriptional repressor protein regulating the transcription factor GATA-3 is supposed to promote type 2 inflammation and eosinophilia [137]. In Hodgkin lymphoma, Hodgkin/Reed Sternberg tumor cells produce TNF- $\alpha$ that stimulates eotaxin production by fibroblasts leading to eosinophil recruitment [138]. Tissue eosinophilia has been associated with poor prognosis [12]. Eosinophils secrete CD30 ligand that via binding to CD30 on Hodgkin cells may promote tumor cell proliferation and survival [12].

Opposite to the protumorigenic functions, eosinophils have been reported to exert antitumorigenic activity. In melanoma patients, the response to immune checkpoint inhibitor therapy correlates with the increase of peripheral blood eosinophil counts $[13,139]$. Moreover, eosinophil activation and degranulation of MBP, as well as an association of eosinophil and $\mathrm{CD} 8+\mathrm{T}$ cells numbers infiltrating the tumor tissue, have been observed, suggesting both direct and indirect effects of eosinophils in tumor defense [13].

\section{Vasculitis}

The diagnosis of eosinophilic granulomatosis with polyangiitis (EGPA) is based on the occurrence of asthma and other allergy symptoms, eosinophilia in blood and tissues followed by eosinophilic granulomas and vasculitis that may affect all organs including skin in the third phase (Fig. 3F) [140]. As potential roles of eosinophils in EGPA pathogenesis, the production of cytokines such as IL-25 shaping Th2 inflammation, degranulation, toxic effects on tissues leading to necrotizing granulomas, and destruction of small to medium-sized vessel walls, as well as the release of tissue factor and activation of platelets contributing to thromboembolism, have been discussed [140]. Antibodies directed against IL-5 or IL-5 receptor have been shown to be effective in EGPA [141-143].

\section{Fibrosis}

Eosinophilic fasciitis (EF) often starts with an edematous phase followed by a bilateral, symmetrical solid hardening of the skin on the limbs why it has been considered a subtype of scleroderma (Fig. 3G) [144]. Blood and tissue eosinophilia occur during the early stages. In addition, a thickened fascia,

Table 2 Antieosinophil targeted therapies

\begin{tabular}{|c|c|c|c|}
\hline Target & Name & Effect on eosinophils & Effective in \\
\hline \multirow[t]{2}{*}{ IL-5 } & Mepolizumab & Production, survival, recruitment, activation & $\begin{array}{l}\text { HES with eosinophilic dermatitis [14] } \\
\text { EGPA [141] } \\
\text { DRESS [95] } \\
\text { Eosinophilic cellulitis [107] } \\
\text { Kimura disease [147] } \\
\text { Urticaria [148] }\end{array}$ \\
\hline & Reslizumab & & $\begin{array}{l}\text { Chronic spontaneous urticaria, cold urticaria [149] } \\
\text { EGPA [143] }\end{array}$ \\
\hline IL-5R $\alpha$ & Benralizumab & Survival, recruitment, activation & $\begin{array}{l}\text { HES [15] } \\
\text { DRESS [97] } \\
\text { EGPA [142] } \\
\text { EPF [123] }\end{array}$ \\
\hline Eotaxin-1 & Bertilimumab & Recruitment & BP Phase 2a Study (NCT02226146), results not available \\
\hline Siglec-8 & Antolimab & $\begin{array}{l}\text { Depletion } \\
\quad+\text { reduction of mast cell activation }\end{array}$ & Chronic spontaneous urticaria $[101,150]$ \\
\hline IL-4/IL-13R $\alpha$ & Dupilumab & $\begin{array}{l}\text { Activation } \\
\quad+\text { decrease of type } 2 \text { inflammation }\end{array}$ & $\begin{array}{l}\text { AD [151] } \\
\text { BP [152] } \\
\text { EDHM [153, 154] }\end{array}$ \\
\hline IL-13 & $\begin{array}{l}\text { Tralokinumab } \\
\text { Lebrikizumab }\end{array}$ & $\begin{array}{l}\text { Activation } \\
\quad+\text { IL-13 production }\end{array}$ & $\mathrm{AD}[155,156]$ \\
\hline Janus kinase & $\begin{array}{l}\text { Tofacitinib Ruxolitinib } \\
\text { Baricitinb Upadacitinib } \\
\text { Abrocitinib }\end{array}$ & $\begin{array}{l}\text { Blocking JAK and STAT3 } \\
+ \text { decrease type } 2 \text { inflammation }\end{array}$ & $\begin{array}{l}\text { HES with cutaneous involvement [157] } \\
\text { AD [158-160] }\end{array}$ \\
\hline
\end{tabular}

$A D$, atopic dermatitis; $B P$, bullous pemphigoid; DRESS, drug rush with eosinophilia and systemic symptoms; EDHM, eosinophilic dermatosis of hematologic malignancy; $E G P A$, eosinophilic granulomatosis and polyangiitis; $E P F$, eosinophilic pustular folliculitis; $H E S$, hypereosinophilic syndrome 
as well as an inflammatory infiltrate of lymphocytes and plasma cells, occasionally a fibrosis of the dermis can be observed on histology [144]. In patients with EF, elevated IL-5 and ECP levels have been detected $[144,145]$. As eosinophils are known to stimulate fibrosis via the release of toxic granule proteins, metalloproteinases, and TGF- $\beta$, they are assumed to contribute to the pathogenesis of EF.

Eosinophils are part of the cutaneous inflammatory infiltrate in systemic sclerosis and localized scleroderma [146]. For the latter, an endothelial injury followed by the recruitment of eosinophils, $\mathrm{T}$ cells, and macrophages, as well as the secretion of fibrogenic cytokines including IL-4, IL-6, and TGF- $\beta$, have been considered as important pathogenic factors [146].

\section{Targeting eosinophils as therapeutic approach}

Over the last decade with the development of targeted therapies, eosinophils have caught attention as treatment targets. Antibodies blocking IL-5 and IL-5 receptor have been approved for asthma and have successfully been tested in hypereosinophilic syndromes. An increasing number of case reports and case series demonstrate the efficacy of mepolizumab, reslizumab, and benralizumab in various eosinophilic dermatoses (Table 2). By reducing type 2 inflammation and thus impacting eosinophil responses, drugs such as dupilumab are effective in many diseases beyond $\mathrm{AD}$

\section{Conclusion}

Eosinophil infiltration in the skin is a frequent finding in a broad spectrum of dermatoses and often an indicative finding for the diagnosis. However, the exact roles of eosinophils need to be defined in most of these diseases. The use of novel targeted therapies and monitoring their effects on clinical signs and symptoms, as well as the numbers and functions of eosinophils including their interactions with tissue specific and inflammatory cells, provide an opportunity to better define the pathogenic role of eosinophils.

Funding Open Access funding provided by Universität Bern. Research of HUS is supported by the Swiss National Science Foundation (grant number 310030 184816) and the Russian Government Program "Recruitment of the Leading Scientists into the Russian Institutions of Higher Education".

Availability of data and material Not applicable.

Code availability Not applicable.

\section{Declarations}

Additional declarations for articles in life science journals that report the results of studies involving humans and/or animals Not applicable.

Ethics approval Not applicable.

Consent to participate Not applicable.

Consent for publication Not applicable.

Competing interests H.U.S. is a consultant for GlaxoSmithKline. DS has been an investigator, advisory board member, or consultant for AbbVie, AstraZeneca, Galderma, LEO, Lilly, Pfizer, Roche Pharma, and Sanofi Genzyme. The other authors declare that they have no conflict of interest.

Open Access This article is licensed under a Creative Commons Attribution 4.0 International License, which permits use, sharing, adaptation, distribution and reproduction in any medium or format, as long as you give appropriate credit to the original author(s) and the source, provide a link to the Creative Commons licence, and indicate if changes were made. The images or other third party material in this article are included in the article's Creative Commons licence, unless indicated otherwise in a credit line to the material. If material is not included in the article's Creative Commons licence and your intended use is not permitted by statutory regulation or exceeds the permitted use, you will need to obtain permission directly from the copyright holder. To view a copy of this licence, visit http://creativecommons.org/licenses/by/4.0/.

\section{References}

1. Ehrlich P (1880) Methodologische Beiträge zur Physiologie und Pathologie der verschiedenen Formen der Leukocyten. Z Klin Med 1:553-560

2. Radonjic-Hösli S, Simon HU (2014) Eosinophils. Chem Immunol Allergy 100:193-204. https://doi.org/10.1159/000358735

3. Valent P, Klion AD, Horny HP, Roufosse F, Gotlib J, Weller PF, Hellmann A, Metzgeroth G, Leiferman KM, Arock M, Butterfield JH, Sperr WR, Sotlar K, Vandenberghe P, Haferlach T, Simon HU, Reiter A, Gleich GJ (2012) Contemporary consensus proposal on criteria and classification of eosinophilic disorders and related syndromes. J Allergy Clin Immunol 130:607-612.e9. https:// doi.org/10.1016/j.jaci.2012.02.019

4. Roth N, Städler S, Lemann M, Hösli S, Simon HU, Simon D (2011) Distinct eosinophil cytokine expression patterns in skin diseases - the possible existence of functionally different eosinophil subpopulations. Allergy. 66:1477-1486. https://doi.org/10. 1111/j.1398-9995.2011.02694.x

5. Simon D, Hoesli S, Roth N, Staedler S, Yousefi S, Simon HU (2011) Eosinophil extracellular DNA traps in skin diseases. J Allergy Clin Immunol 127:194-199. https://doi.org/10.1016/j. jaci.2010.11.002

6. de Graauw E, Sitaru C, Horn M, Borradori L, Yousefi S, Simon HU, Simon D (2017) Evidence for a role of eosinophils in blister formation in bullous pemphigoid. Allergy. 72:1105-1113. https:// doi.org/10.1111/all.13131

7. Davis MD, Plager DA, George TJ, Weiss EA, Gleich GJ, Leiferman KM (2003) Interactions of eosinophil granule proteins with skin: limits of detection, persistence, and 
vasopermeabilization. J Allergy Clin Immunol 112:988-994. https://doi.org/10.1016/j.jaci.2003.08.028

8. Morshed M, Yousefi S, Stöckle C, Simon HU, Simon D (2012) Thymic stromal lymphopoietin stimulates the formation of eosinophil extracellular traps. Allergy. 67:1127-1137. https://doi.org/ 10.1111/j.1398-9995.2012.02868.x

9. Kunsleben N, Rüdrich U, Gehring M, Novak N, Kapp A, Raap U (2015) IL-31 Induces chemotaxis, calcium mobilization, release of reactive oxygen species, and CCL26 in eosinophils, which are capable to release IL-31. J Invest Dermatol 135:1908-1911. https://doi.org/10.1038/jid.2015.106

10. Rüdrich U, Gehring M, Papakonstantinou E, Illerhaus A, Engmann J, Kapp A, Hartmann K, Meyer NH, Gibbs BF, Raap U (2018) Eosinophils are a major source of Interleukin-31 in bullous pemphigoid. Acta Derm Venereol 98:766-771. https:// doi.org/10.2340/00015555-2951

11. Simon HU, Plötz S, Simon D, Seitzer U, Braathen LR, Menz G, Straumann A, Dummer R, Levi-Schaffer F (2003) Interleukin-2 primes eosinophil degranulation in hypereosinophilia and Wells syndrome. Eur J Immunol 33:834-839. https://doi.org/10.1002/ eji.200323727

12. von Wasielewski R, Seth S, Franklin J, Fischer R, Hübner K, Hansmann ML, Diehl V, Georgii A (2000 Feb 15) Tissue eosinophilia correlates strongly with poor prognosis in nodular sclerosing Hodgkin's disease, allowing for known prognostic factors. Blood. 95(4):1207-1213

13. Simon SCS, Hu X, Panten J, Grees M, Renders S, Thomas D, Weber R, Schulze TJ, Utikal J, Umansky V (2020) Eosinophil accumulation predicts response to melanoma treatment with immune checkpoint inhibitors. Oncoimmunology. 9:1727116. https://doi.org/10.1080/2162402X.2020.1727116

14. Plötz SG, Simon HU, Darsow U, Simon D, Vassina E, Yousefi S, Hein R, Smith T, Behrendt H, Ring J (2003) Use of an antiinterleukin-5 antibody in the hypereosinophilic syndrome with eosinophilic dermatitis. N Engl J Med 349:2334-2339. https:// doi.org/10.1056/NEJMoa031261

15. Kuang FL, Legrand F, Makiya M, Ware J, Wetzler L, Brown T, Magee T, Piligian B, Yoon P, Ellis JH, Sun X, Panch SR, Powers A, Alao H, Kumar S, Quezado M, Yan L, Lee N, Kolbeck R, Newbold P, Goldman M, Fay MP, Khoury P, Maric I, Klion AD (2019) Benralizumab for PDGFRA-negative hypereosinophilic syndrome. N Engl J Med 380:1336-1346. https://doi.org/10.1056/NEJMoa1812185

16. Kvarnhammar AM, Cardell LO (2012) Pattern-recognition receptors in human eosinophils. Immunology. 136:11-20. https://doi. $\operatorname{org} / 10.1111 / \mathrm{j} .1365-2567.2012 .03556 . x$

17. Simon HU, Yousefi S, Germic N, Arnold IC, Haczku A, Karaulov AV, Simon D, Rosenberg HF (2020) The cellular functions of eosinophils: Collegium Internationale Allergologicum (CIA) Update 2020. Int Arch Allergy Immunol 181:11-23. https://doi. org $/ 10.1159 / 000504847$

18. Gigon L, Yousefi S, Karaulov A, Simon HU (2021) Mechanisms of toxicity mediated by neutrophil and eosinophil granule proteins. Allergol Int 70:30-38. https://doi.org/10.1016/j.alit.2020.11.003

19. Butterworth AE, Wassom DL, Gleich GJ, Loegering DA, David JR (1979) Damage to schistosomula of Schistosoma mansoni induced directly by eosinophil major basic protein. J Immunol 122: 221-229. https://doi.org/10.1084/jem.150.6.1456

20. Gleich GJ, Loegering DA, Bell MP, Checkel JL, Ackerman SJ, McKean DJ (1986) Biochemical and functional similarities between human eosinophil-derived neurotoxin and eosinophil cationic protein: homology with ribonuclease. Proc Natl Acad Sci U S A 83:3146e50. https://doi.org/10.1073/pnas.83.10.3146

21. Lehrer RI, Szklarek D, Barton A, Ganz T, Hamann KJ, Gleich GJ (1989) Antibacterial properties of eosinophil major basic protein and eosinophil cationic protein. J Immunol 142:4428-4434
22. Rosenberg HF (1995) Recombinant human eosinophil cationic protein. Ribonuclease activity is not essential for cytotoxicity. J Biol Chem 270:7876-7881. https://doi.org/10.1074/jbc.270.14. 7876

23. Rosenberg HF (2008) Eosinophil-derived neurotoxin / RNase 2: connecting the past, the present and the future. Curr Pharm Biotechnol 9:135-140. https://doi.org/10.2174/ 138920108784567236

24. Yousefi S, Gold JA, Andina N, Lee JJ, Kelly AM, Kozlowski E, Schmid I, Straumann A, Reichenbach J, Gleich GJ, Simon HU (2008) Catapult-like release of mitochondrial DNA by eosinophils contributes to antibacterial defense. Nat Med 14:949-953. https:// doi.org/10.1038/nm. 1855

25. Germic N, Fettrelet T, Stojkov D, Hosseini A, Horn MP, Karaulov A, Simon D, Yousefi S, Simon HU (2021) The release kinetics of eosinophil peroxidase and mitochondrial DNA is different in association with eosinophil extracellular trap formation. Cells. 10: 306. https://doi.org/10.3390/cells10020306

26. Soragni A, Yousefi S, Stoeckle C, Soriaga AB, Sawaya MR, Kozlowski E, Schmid I, Radonjic-Hoesli S, Boutet S, Williams GJ, Messerschmidt M, Seibert MM, Cascio D, Zatsepin NA, Burghammer M, Riekel C, Colletier JP, Riek R, Eisenberg DS, Simon HU (2015) Toxicity of eosinophil MBP is repressed by intracellular crystallization and promoted by extracellular aggregation. Mol Cell 57:1011-1021. https://doi.org/10.1016/j.molcel. 2015.01.026

27. Melo RCN, Weller PF (2018) Contemporary understanding of the secretory granules in human eosinophils. J Leukoc Biol 104:8593. https://doi.org/10.1002/JLB.3MR1217-476R

28. Moqbel R, Coughlin JJ (2006 Jun 6) Differential secretion of cytokines. Sci STKE 2006(338):pe26. https://doi.org/10.1126/ stke.3382006pe26

29. Spencer LA, Bonjour K, Melo RC, Weller PF (2014) Eosinophil secretion of granule-derived cytokines. Front Immunol 5:496. https://doi.org/10.3389/fimmu.2014.00496

30. Neves JS, Perez SA, Spencer LA, Melo RC, Reynolds L, Ghiran I, Mahmudi-Azer S, Odemuyiwa SO, Dvorak AM, Moqbel R, Weller PF (2008) Eosinophil granules function extracellularly as receptor-mediated secretory organelles. Proc Natl Acad Sci U S A 105:18478-18483. https://doi.org/10.1073/pnas.0804547105

31. Neves JS, Radke AL, Weller PF (2010) Cysteinyl leukotrienes acting via granule membrane-expressed receptors elicit secretion from within cell-free human eosinophil granules. J Allergy Clin Immunol 125:477-482. https://doi.org/10.1016/j.jaci.2009.11. 029

32. Radonjic-Hoesli S, Wang X, de Graauw E, Stoeckle C, StypRekowska B, Hlushchuk R, Simon D, Spaeth PJ, Yousefi S, Simon HU (2017) Adhesion-induced eosinophil cytolysis requires the receptor-interacting protein kinase 3 (RIPK3)-mixed lineage kinase-like (MLKL) signaling pathway, which is counterregulated by autophagy. J Allergy Clin Immunol 140:1632-1642. https:// doi.org/10.1016/j.jaci.2017.01.044

33. Yousefi S, Simon HU (2016) NETosis - does it really represent nature's "suicide bomber"? Front Immunol 7:328. https://doi.org/ 10.3389/fimmu.2016.00328

34. Yousefi S, Simon D, Simon HU (2012) Eosinophil extracellular DNA traps: molecular mechanisms and potential roles in disease. Curr Opin Immunol 24:736e9. https://doi.org/10.1016/j.coi.2012. 08.010

35. Finotto S, Ohno I, Marshall JS, Gauldie J, Denburg JA, Dolovich J, Clark DA, Jordana M (1994) TNF-alpha production by eosinophils in upper airways inflammation (nasal polyposis). J Immunol 153:2278-2289

36. Straumann A, Conus S, Grzonka P, Kita H, Kephart G, Bussmann C, Beglinger C, Smith DA, Patel J, Byrne M, Simon HU (2010) Anti-interleukin-5 antibody treatment (mepolizumab) in active 
eosinophilic oesophagitis: a randomised, placebo-controlled, double-blind trial. Gut. 59:21-30. https://doi.org/10.1136/gut. 2009.178558

37. Flood-Page P, Menzies-Gow A, Phipps S, Ying S, Wangoo A, Ludwig MS, Barnes N, Robinson D, Kay AB (2003) Anti-IL-5 treatment reduces deposition of ECM proteins in the bronchial subepithelial basement membrane of mild atopic asthmatics. J Clin Invest 112:1029-1036. https://doi.org/10.1172/JCI17974

38. Richter A, Puddicombe SM, Lordan JL, Bucchieri F, Wilson SJ, Djukanovic R, Dent G, Holgate ST, Davies DE (2001) The contribution of interleukin (IL)-4 and IL-13 to the epithelialmesenchymal trophic unit in asthma. Am J Respir Cell Mol Biol 25:385-391. https://doi.org/10.1165/ajrcmb.25.3.4437

39. Puxeddu I, Bader R, Piliponsky AM, Reich R, Levi-Schaffer F, Berkman N (2006) The CC chemokine eotaxin/CCL11 has a selective profibrogenic effect on human lung fibroblasts. J Allergy Clin Immunol 117:103-110. https://doi.org/10.1016/j.jaci.2005. 08.057

40. Zheng T, Zhu Z, Wang J, Homer RJ, Elias JA (2001 Oct) IL-11: insights in asthma from overexpression transgenic modeling. J Allergy Clin Immunol 108(4):489-496. https://doi.org/10.1067/ mai.2001.118510

41. Klion AD, Nutman TB (2004) The role of eosinophils in host defense against helminth parasites. J Allergy Clin Immunol 113: 30-37. https://doi.org/10.1016/j.jaci.2003.10.050

42. Rosenberg HF (2015) Eosinophil-derived neurotoxin (EDN/ RNase 2) and the mouse eosinophil-associated RNases (mEars): expanding roles in promoting host defense. Int J Mol Sci 16: 15442-15455. https://doi.org/10.3390/ijms160715442

43. Samarasinghe AE, Melo RC, Duan S, LeMessurier KS, Liedmann S, Surman SL, Lee JJ, Hurwitz JL, Thomas PG, McCullers JA (2017) Eosinophils promote antiviral immunity in mice infected with influenza A virus. J Immunol 198:3214-3226. https://doi. org/10.4049/jimmunol.1600787

44. Leiferman KM, Peters MS (2018) Eosinophil-related disease and the skin. J Allergy Clin Immunol Pract 6:1462-1482.e6. https:// doi.org/10.1016/j.jaip.2018.06.002

45. Altman K, Chang C (2013 Aug) Pathogenic intracellular and autoimmune mechanisms in urticaria and angioedema. Clin Rev Allergy Immunol 45(1):47-62. https://doi.org/10.1007/s12016012-8326-y

46. Amber KT, Chernyavsky A, Agnoletti AF, Cozzani E, Grando SA (2018) Mechanisms of pathogenic effects of eosinophil cationic protein and eosinophil-derived neurotoxin on human keratinocytes. Exp Dermatol 27:1322-1327. https://doi.org/10. 1111/exd.13782

47. Carretero R, Sektioglu IM, Garbi N, Salgado OC, Beckhove P, Hämmerling GJ (2015) Eosinophils orchestrate cancer rejection by normalizing tumor vessels and enhancing infiltration of CD8(+ ) T cells. Nat Immunol 16:609-617. https://doi.org/10.1038/ni. 3159

48. Lucarini V, Ziccheddu G, Macchia I, LaSorsa V, Peschiaroli F, Buccione C, Sistigu A, Sanchez M, Andreone S, D'Urso MT et al (2017) IL-33 restricts tumor growth and inhibits pulmonary metastasis melanoma bearing mice through eosinophils. OncoImmunology 6:e1317420. https://doi.org/10.1080/ 2162402X.2017.1317420

49. Arnold IC, Artola-Boran M, Gurtner A, Bertram K, Bauer M, Frangez Z, Becher B, Kopf M, Yousefi S, Simon HU, Tzankov A, Müller A (2020) The GM-CSF-IRF5 signaling axis in eosinophils promotes antitumor immunity through activation of type $1 \mathrm{~T}$ cell responses. J Exp Med 217:e20190706. https://doi.org/10. 1084/jem.20190706

50. Ortonne N, Valeyrie-Allanore L, Bastuji-Garin S, Wechsler J, de Feraudy S, Duong TA, Delfau-Larue MH, Chosidow O, Wolkenstein P, Roujeau JC (2015) Histopathology of drug rash with eosinophilia and systemic symptoms syndrome: a morphological and phenotypical study. Br J Dermatol 173:50-58. https:// doi.org/10.1111/bjd.13683

51. Nakashima C, Ishida Y, Kitoh A, Otsuka A, Kabashima K (2019) Interaction of peripheral nerves and mast cells, eosinophils, and basophils in the development of pruritus. Exp Dermatol 28:14051411. https://doi.org/10.1111/exd.14014

52. Sonkoly E, Muller A, Lauerma AI, Pivarcsi A, Soto H, Kemeny L, Alenius H, Dieu-Nosjean MC, Meller S, Rieker J, Steinhoff M, Hoffmann TK, Ruzicka T, Zlotnik A, Homey B (2006) IL-31: a new link between $T$ cells and pruritus in atopic skin inflammation. J Allergy Clin Immunol 117:411-417. https://doi.org/10.1016/j. jaci.2005.10.033

53. Hashimoto T, Nattkemper LA, Kim HS, Kursewicz CD, Fowler E, Shah SM, Nanda S, Fayne RA, Paolini JF, Romanelli P, Yosipovitch G (2021 Jan 11) Itch intensity in prurigo nodularis is closely related to dermal interleukin-31, oncostatin M, IL-31 receptor alpha and oncostatin $\mathrm{M}$ receptor beta. Exp Dermatol. https://doi.org/10.1111/exd.14279

54. Kim HJ, Zeidi M, Bonciani D, Pena SM, Tiao J, Sahu S, Werth VP (2018) Itch in dermatomyositis: the role of increased skin interleukin-31. Br J Dermatol 179:669-678. https://doi.org/10. 1111/bjd.16498

55. Shimizu K, Andoh T, Makino T, Yoshihisa Y, Mizawa M, Shimizu T (2019) Mechanisms of itching in mycosis fungoides: grade of itching correlates with eosinophil infiltration and kallikrein 5 expression. Eur J Dermatol 29:268-273. https://doi.org/ 10.1684/ejd.2019.3560

56. Simon D, Simon HU (2007) Eosinophilic disorders. J Allergy Clin Immunol 119:1291-1300. https://doi.org/10.1016/j.jaci.2007.02. 010

57. Simon D, Simon HU (2019) Therapeutic strategies for eosinophilic dermatoses. Curr Opin Pharmacol 46:29-33. https://doi.org/10. 1016/j.coph.2019.01.002

58. Kuang FL, Klion AD (2017) Biologic agents for the treatment of hypereosinophilic syndromes. J Allergy Clin Immunol Pract 5: 1502-1509. https://doi.org/10.1016/j.jaip.2017.08.001

59. Radonjic-Hoesli S, Valent P, Klion AD, Wechsler ME, Simon HU (2015) Novel targeted therapies for eosinophil-associated diseases and allergy. Annu Rev Pharmacol Toxicol 55:633-656. https:// doi.org/10.1146/annurev-pharmtox-010814-124407

60. Simon D, Wollenberg A, Renz H, Simon HU (2019) Atopic dermatitis: Collegium Internationale Allergologicum (CIA) Update 2019. Int Arch Allergy Immunol 178:207-218. https://doi.org/ 10.1159/000497383

61. Kiehl P, Falkenberg K, Vogelbruch M, Kapp A (2001) Tissue eosinophilia in acute and chronic atopic dermatitis: a morphometric approach using quantitative image analysis of immunostaining. Br J Dermatol 145:720-729. https://doi.org/10.1046/j.1365-2133. 2001.04456.x

62. Walker C, Kägi MK, Ingold P, Braun P, Blaser K, BruijnzeelKoomen CA, Wüthrich B (1993) Atopic dermatitis: correlation of peripheral blood $\mathrm{T}$ cell activation, eosinophilia and serum factors with clinical severity. Clin Exp Allergy 23:145-153. https:// doi.org/10.1111/j.1365-2222.1993.tb00310.x

63. Cheng JF, Ott NL, Peterson EA, George TJ, Hukee MJ, Gleich GJ, Leiferman KM (1997) Dermal eosinophils in atopic dermatitis undergo cytolytic degeneration. J Allergy Clin Immunol 99:683692. https://doi.org/10.1016/s0091-6749(97)70031-9

64. Leiferman KM, Ackerman SJ, Sampson HA, Haugen HS, Venencie PY, Gleich GJ (1985) Dermal deposition of eosinophil-granule major basic protein in atopic dermatitis. Comparison with onchocerciasis. N Engl J Med 313:282-285. https://doi.org/10.1056/NEJM198508013130502

65. Ruzicka T, Hanifin JM, Furue M, Pulka G, Mlynarczyk I, Wollenberg A, Galus R, Etoh T, Mihara R, Yoshida H, Stewart 
J, Kabashima K, XCIMA Study Group (2017) Anti-Interleukin31 receptor A antibody for atopic dermatitis. N Engl J Med 376: 826-835. https://doi.org/10.1056/NEJMoa1606490

66. Oldhoff JM, Darsow U, Werfel T, Katzer K, Wulf A, Laifaoui J, Hijnen DJ, Plötz S, Knol EF, Kapp A, Bruijnzeel-Koomen CA, Ring J, de Bruin-Weller MS (2005) Anti-IL-5 recombinant humanized monoclonal antibody (mepolizumab) for the treatment of atopic dermatitis. Allergy. 60(5):693-696. https://doi.org/10. 1111/j.1398-9995.2005.00791.x

67. Kang EG, Narayana PK, Pouliquen IJ, Lopez MC, FerreiraCornwell MC, Getsy JA (2020) Efficacy and safety of mepolizumab administered subcutaneously for moderate to severe atopic dermatitis. Allergy 75:950-953. https://doi.org/10.1111/all. 14050

68. Esser PR, Martin SF (2017) Pathomechanisms of contact sensitization. Curr Allergy Asthma Rep 17:83. https://doi.org/10.1007/ s11882-017-0752-8

69. Simon D, Aeberhard C, Erdemoglu Y, Simon HU (2014) Th17 cells and tissue remodeling in atopic and contact dermatitis. Allergy. 69:125-131. https://doi.org/10.1111/all.12351

70. Walton SF, Oprescu FI (2013) Immunology of scabies and translational outcomes: identifying the missing links. Curr Opin Infect Dis 26:116-122. https://doi.org/10.1097/QCO. 0b013e32835eb8a6

71. Said S, Jay S, Kang J, Liem WH, Jensen JL, Jeffes EW 3rd. (1993) Localized bullous scabies. Uncommon presentation of scabies. Am J Dermatopathol 15:590-593. https://doi.org/10.1097/ 00000372-199312000-00015

72. Ionescu MA, Rivet J, Daneshpouy M, Briere J, Morel P, Janin A (2005) In situ eosinophil activation in 26 primary cutaneous T-cell lymphomas with blood eosinophilia. J Am Acad Dermatol 52:3239. https://doi.org/10.1016/j.jaad.2004.03.003

73. Wilcox RA (2016) Cutaneous T-cell lymphoma: 2016 update on diagnosis, risk-stratification, and management. Am J Hematol 91: 151-165. https://doi.org/10.1002/ajh.24233

74. Jawed SI, Myskowski PL, Horwitz S, Moskowitz A, Querfeld C (2014) Primary cutaneous T-cell lymphoma (mycosis fungoides and Sézary syndrome): part I. Diagnosis: clinical and histopathologic features and new molecular and biologic markers. J Am Acad Dermatol 70:205.e1-205.16. https://doi.org/10.1016/j.jaad. 2013.07.049

75. Miyagaki T, Sugaya M, Fujita H, Ohmatsu H, Kakinuma T, Kadono T, Tamaki K, Sato S (2010) Eotaxins and CCR3 interaction regulates the Th2 environment of cutaneous T-cell lymphoma. J Invest Dermatol 130:2304-2311. https://doi.org/10.1038/ jid.2010.128

76. Tancrède-Bohin $\mathrm{E}$, Ionescu MA, de La Salmonière $\mathrm{P}$, Dupuy A, Rivet J, Rybojad M, Dubertret L, Bachelez H, Lebbé C, Morel P (2004) Prognostic value of blood eosinophilia in primary cutaneous T-cell lymphomas. Arch Dermatol 140:1057-1061. https:// doi.org/10.1001/archderm.140.9.1057

77. Ogbogu PU, Bochner BS, Butterfield JH, Gleich GJ, Huss-Marp J, Kahn JE, Leiferman KM, Nutman TB, Pfab F, Ring J, Rothenberg ME, Roufosse F, Sajous MH, Sheikh J, Simon D, Simon HU, Stein ML, Wardlaw A, Weller PF, Klion AD (2009) Hypereosinophilic syndrome: a multicenter, retrospective analysis of clinical characteristics and response to therapy. J Allergy Clin Immunol 124:1319-25.e3. https://doi.org/10.1016/j.jaci.2009.09. 022

78. Simon HU, Plötz SG, Dummer R, Blaser K (1999) Abnormal clones of $\mathrm{T}$ cells producing interleukin-5 in idiopathic eosinophilia. N Engl J Med 341:1112-1120. https://doi.org/10.1056/ NEJM199910073411503

79. Simon HU, Plötz SG, Simon D, Dummer R, Blaser K (2001) Clinical and immunological features of patients with interleukin- 5-producing $\mathrm{T}$ cell clones and eosinophilia. Int Arch Allergy Immunol 124:242-245. https://doi.org/10.1159/000053723

80. Krooks J, Minkov M, Weatherall AG (2018) Langerhans cell histiocytosis in children: Diagnosis, differential diagnosis, treatment, sequelae, and standardized follow-up. J Am Acad Dermatol 78(6):1047-1056. https://doi.org/10.1016/j.jaad.2017.05.060

81. Egeler RM, Favara BE, van Meurs M, Laman JD, Claassen E (1999) Differential In situ cytokine profiles of Langerhans-like cells and T cells in Langerhans cell histiocytosis: abundant expression of cytokines relevant to disease and treatment. Blood. 94: 4195-4201

82. Egeler RM, van Halteren AG, Hogendoorn PC, Laman JD, Leenen PJ (2010) Langerhans cell histiocytosis: fascinating dynamics of the dendritic cell-macrophage lineage. Immunol Rev 234:213-232. https://doi.org/10.1111/j.0105-2896.2009.00883.x

83. Pichler WJ (2003) Delayed drug hypersensitivity reactions. Ann Intern Med 139:683-693. https://doi.org/10.7326/0003-4819139-8-200310210-00012

84. Schrijvers R, Gilissen L, Chiriac AM, Demoly P (2015) Pathogenesis and diagnosis of delayed-type drug hypersensitivity reactions, from bedside to bench and back. Clin Transl Allergy 5: 31. https://doi.org/10.1186/s13601-015-0073-8

85. Kuijper EC, French LE, Tensen CP, Vermeer MH, Bouwes Bavinck JN (2020) Clinical and pathogenic aspects of the severe cutaneous adverse reaction epidermal necrolysis (EN). J Eur Acad Dermatol Venereol 34:1957-1971. https://doi.org/10.1111/jdv. 16339

86. Shiohara T, Mizukawa Y (2019) Drug-induced hypersensitivity syndrome (DiHS)/drug reaction with eosinophilia and systemic symptoms (DRESS): an update in 2019. Allergol Int 68:301308. https://doi.org/10.1016/j.alit.2019.03.006

87. Kardaun SH, Sekula P, Valeyrie-Allanore L, Liss Y, Chu CY, Creamer D, Sidoroff A, Naldi L, Mockenhaupt M, Roujeau JC, RegiSCAR study group (2013) Drug reaction with eosinophilia and systemic symptoms (DRESS): an original multisystem adverse drug reaction. Results from the prospective RegiSCAR study. Br J Dermatol 169:1071-1080. https://doi.org/10.1111/ bjd. 12501

88. Shiohara T, Iijima M, Ikezawa Z, Hashimoto K (2007) The diagnosis of a DRESS syndrome has been sufficiently established on the basis of typical clinical features and viral reactivations. Br J Dermatol 156:1083-1084. https://doi.org/10.1111/j.1365-2133. 2007.07807.x

89. Walsh S, Diaz-Cano S, Higgins E, Morris-Jones R, Bashir S, Bernal W, Creamer D (2013) Drug reaction with eosinophilia and systemic symptoms: is cutaneous phenotype a prognostic marker for outcome? A review of clinicopathological features of 27 cases. Br J Dermatol 168:391-401. https://doi.org/10.1111/bjd. 12081

90. Kardaun SH, Sidoroff A, Valeyrie-Allanore L, Halevy S, Davidovici BB, Mockenhaupt M, Roujeau JC (2007) Variability in the clinical pattern of cutaneous side-effects of drugs with systemic symptoms: does a DRESS syndrome really exist? Br J Dermatol 156:609-611. https://doi.org/10.1111/j.1365-2133. 2006.07704.x

91. Ang CC, Wang YS, Yoosuff EL, Tay YK (2010) Retrospective analysis of drug-induced hypersensitivity syndrome: a study of 27 patients. J Am Acad Dermatol 63:219-227. https://doi.org/10. 1016/j.jaad.2009.08.050

92. Musette P, Janela B (2017) New insights into drug reaction with eosinophilia and systemic symptoms pathophysiology. Front Med (Lausanne) 4:179. https://doi.org/10.3389/fmed.2017.00179

93. Chi MH, Hui RC, Yang CH, Lin JY, Lin YT, Ho HC, Chung WH, Kuo TT (2014) Histopathological analysis and clinical correlation of drug reaction with eosinophilia and systemic symptoms 
(DRESS). Br J Dermatol 170:866-873. https://doi.org/10.1111/ bjd. 12783

94. Choquet-Kastylevsky G, Intrator L, Chenal C, Bocquet H, Revuz J, Roujeau JC (1998) Increased levels of interleukin 5 are associated with the generation of eosinophilia in drug-induced hypersensitivity syndrome. Br J Dermatol 139:1026-1032. https://doi.org/ 10.1046/j.1365-2133.1998.02559.x

95. Ange N, Alley S, Fernando SL, Coyle L, Yun J (2018) Drug Reaction with Eosinophilia and Systemic Symptoms (DRESS) syndrome successfully treated with mepolizumab. J Allergy Clin Immunol Pract 6:1059-1060. https://doi.org/10.1016/j.jaip.2017. 10.020

96. Thein OS, Sutton B, Thickett DR, Parekh D (2019) Mepolizumab rescue therapy for acute pneumonitis secondary to DRESS. BMJ Case Rep 12:e231355. https://doi.org/10.1136/bcr-2019-231355

97. Schmid-Grendelmeier P, Steiger P, Naegeli MC, Kolm I, Lang $\mathrm{CCV}$, Maverakis E, Brüggen MC (2021) Benralizumab for severe DRESS in two COVID-19 patients. J Allergy Clin Immunol Pract 9:481-483.e2. https://doi.org/10.1016/j.jaip.2020.09.039

98. Maurer M, Eyerich K, Eyerich S, Ferrer M, Gutermuth J, Hartmann K, Jakob T, Kapp A, Kolkhir P, Larenas-Linnemann D, Park HS, Pejler G, Sánchez-Borges M, Schäkel K, Simon D, Simon HU, Weller K, Zuberbier T, Metz M (2020) Urticaria: Collegium Internationale Allergologicum (CIA) Update 2020. Int Arch Allergy Immunol 181:321-333. https://doi.org/10. $1159 / 000507218$

99. Cugno M, Marzano AV, Tedeschi A, Fanoni D, Venegoni L, Asero R (2009) Expression of tissue factor by eosinophils in patients with chronic urticaria. Int Arch Allergy Immunol 148:170 174. https://doi.org/10.1159/000155748

100. Tedeschi A, Asero R, Marzano AV, Lorini M, Fanoni D, Berti E, Cugno M (2009) Plasma levels and skin-eosinophil-expression of vascular endothelial growth factor in patients with chronic urticaria. Allergy. 64:1616-1622. https://doi.org/10.1111/j.1398-9995. 2009.02069.x

101. Altrichter S, Frischbutter S, Fok JS, Kolkhir P, Jiao Q, Skov PS, Metz M, Church MK, Maurer M (2020) The role of eosinophils in chronic spontaneous urticaria. J Allergy Clin Immunol 145:1510 1516. https://doi.org/10.1016/j.jaci.2020.03.005

102. Kolkhir P, Church MK, Altrichter S, Skov PS, Hawro T, Frischbutter S, Metz M, Maurer M (2020) Eosinopenia, in Chronic spontaneous urticaria, is associated with high disease activity, autoimmunity, and poor response to treatment. J Allergy Clin Immunol Pract 8:318-325.e5. https://doi.org/10. 1016/j.jaip.2019.08.025

103. Weins AB, Biedermann T, Weiss T, Weiss JM (2016) WellsSyndrom. J Dtsch Dermatol Ges 14:989-994. https://doi.org/10. 1111/ddg.13132_g

104. Simon HU, Rothenberg ME, Bochner BS, Weller PF, Wardlaw AJ, Wechsler ME, Rosenwasser LJ, Roufosse F, Gleich GJ, Klion AD (2010) Refining the definition of hypereosinophilic syndrome. J Allergy Clin Immunol 126:45-49. https://doi.org/10.1016/j.jaci. 2010.03.042

105. Trüeb RM, Lübbe J, Torricelli R, Panizzon RG, Wüthrich B, Burg G (1997 Feb) Eosinophilic myositis with eosinophilic cellulitis like skin lesions. Association with increased serum levels of eosinophil cationic protein and interleukin-5. Arch Dermatol 133(2): 203-206

106. Peters MS, Schroeter AL, Gleich GJ (1983) Immunofluorescence identification of eosinophil granule major basic protein in the flame figures of Wells' syndrome. Br J Dermatol 109:141-148. https://doi.org/10.1111/j.1365-2133.1983.tb07074.x

107. Herout S, Bauer WM, Schuster C, Stingl G (2018) Eosinophilic cellulitis (Wells syndrome) successfully treated with mepolizumab. JAAD Case Rep 4:548-550. https://doi.org/10. 1016/j.jdcr.2018.02.011
108. Gleich GJ, Schroeter AL, Marcoux JP, Sachs MI, O'Connell EJ, Kohler PF (1984) Episodic angioedema associated with eosinophilia. N Engl J Med 310:1621-1626. https://doi.org/10.1056/ NEJM198406213102501

109. Khoury P, Herold J, Alpaugh A, Dinerman E, Holland-Thomas N, Stoddard J, Gurprasad S, Maric I, Simakova O, Schwartz LB, Fong J, Lee CC, Xi L, Wang Z, Raffeld M, Klion AD (2015) Episodic angioedema with eosinophilia (Gleich syndrome) is a multilineage cell cycling disorder. Haematologica. 100:300-307. https://doi.org/10.3324/haematol.2013.091264

110. Bertrand V, Boccara O, Filhon B, Manca F, Lefèvre G, Groh M, Kahn JE (2020) Episodic angioedema with eosinophilia (Gleich syndrome) in children: a clinical review. Pediatr Allergy Immunol 31:297-302. https://doi.org/10.1111/pai.13173

111. Matucci A, Liotta F, Vivarelli E, Dies L, Annunziato F, Piccinni MP, Nencini F, Pratesi S, Maggi E, Vultaggio A (2018) Efficacy and safety of mepolizumab (anti-Interleukin-5) treatment in Gleich's Syndrome. Front Immunol 9:1198. https://doi.org/10. 3389/fimmu.2018.01198

112. Butterfield JH (2021) Successful long-term control of the syndrome of episodic angioedema with eosinophilia (Gleich Syndrome) with low-dose imatinib mesylate and prednisone. J Investig Med High Impact Case Rep 9:2324709620987691. https://doi.org/10.1177/2324709620987691

113. Massone C, Cerroni L, Heidrun N, Brunasso AM, Nunzi E, Gulia A, Ambros-Rudolph CM (2014) Histopathological diagnosis of atopic eruption of pregnancy and polymorphic eruption of pregnancy: a study on 41 cases. Am J Dermatopathol 36:812-821. https://doi.org/10.1097/DAD.0000000000000067

114. Rico MJ, Benning C, Weingart ES, Streilein RD, Hall RP 3rd. (1999) Characterization of skin cytokines in bullous pemphigoid and pemphigus vulgaris. Br J Dermatol 140:1079-1086. https:// doi.org/10.1046/j.1365-2133.1999.02907.x

115. Wakugawa M, Nakamura K, Hino H, Toyama K, Hattori N, Okochi H, Yamada H, Hirai K, Tamaki K, Furue M (2000) Elevated levels of eotaxin and interleukin-5 in blister fluid of bullous pemphigoid: correlation with tissue eosinophilia. Br J Dermatol 143:112-116. https://doi.org/10.1046/j.1365-2133. 2000.03599.x

116. Salz M, Haeberle S, Hoffmann J, Enk AH, Hadaschik EN (2017) Elevated IL-31 serum levels in bullous pemphigoid patients correlate with eosinophil numbers and are associated with BP180IgE. J Dermatol Sci 87:309-311. https://doi.org/10.1016/j. jdermsci.2017.07.019

117. Simon D, Yousefi S, Cazzaniga S, Bürgler C, Radonjic S, Houriet C, Heidemeyer K, Klötgen HW, Kozlowski E, Borradori L, Simon HU (2020 Mar) Mepolizumab failed to affect bullous pemphigoid: a randomized, placebo-controlled, double-blind phase 2 pilot study. Allergy. 75(3):669-672. https://doi.org/10.1111/all. 13950

118. Zaraa I, Sellami A, Bouguerra C, Sellami MK, Chelly I, Zitouna M, Makni S, Hmida AB, Mokni M, Osman AB (2011) Pemphigus vegetans: a clinical, histological, immunopathological and prognostic study. J Eur Acad Dermatol Venereol 25:1160-1167. https://doi.org/10.1111/j.1468-3083.2010.03939.x

119. Berlin AL, Paller AS, Chan LS (2002) Incontinentia pigmenti: a review and update on the molecular basis of pathophysiology. $\mathrm{J}$ Am Acad Dermatol 47:169-187. https://doi.org/10.1067/mjd. 2002.125949

120. Jean-Baptiste S, O'Toole EA, Chen M, Guitart J, Paller A, Chan LS (2002) Expression of eotaxin, an eosinophil-selective chemokine, parallels eosinophil accumulation in the vesiculobullous stage of incontinentia pigmenti. Clin Exp Immunol 127:470 478. https://doi.org/10.1046/j.1365-2249.2002.01755.x 
121. Rothenberg ME (1999) Eotaxin. An essential mediator of eosinophil trafficking into mucosal tissues. Am J Respir Cell Mol Biol 21:291-295. https://doi.org/10.1165/ajrcmb.21.3.f160

122. Nakahigashi K, Doi H, Otsuka A, Hirabayashi T, Murakami M, Urade Y, Zouboulis CC, Tanizaki H, Egawa G, Miyachi Y, Kabashima K (2012) PGD2 induces eotaxin-3 via PPAR $\gamma$ from sebocytes: a possible pathogenesis of eosinophilic pustular folliculitis. J Allergy Clin Immunol 129:536-543. https://doi.org/10. 1016/j.jaci.2011.11.034

123. Bürgler C, Guillet C, Kolm I, Theiler M, Schmid-Grendelmeier P, Kroiss S, Weibel L (2021) Treatment of eosinophilic pustular folliculitis with benralizumab in a 13-year-old girl. J Eur Acad Dermatol Venereol. https://doi.org/10.1111/jdv.17181

124. Weigelt N, Metze D, Ständer S (2010) Prurigo nodularis: systematic analysis of 58 histological criteria in 136 patients. J Cutan Pathol 37:578-586. https://doi.org/10.1111/j.1600-0560.2009. 01484.x

125. Perez GL, Peters MS, Reda AM, Butterfield JH, Peterson EA, Leiferman KM (1993 Jul) Mast cells, neutrophils, and eosinophils in prurigo nodularis. Arch Dermatol 129(7):861-865

126. Zeidler C, Ständer S (2016) The pathogenesis of Prurigo nodularis-'Super-Itch' in exploration. Eur J Pain 20:37-40. https://doi.org/10.1002/ejp.767

127. Gauger A, Ronet C, Schnopp C, Abeck D, Hein R, Köhn F-M, Ring J, Ollert M, Mempel M (2005) High local interleukin 5 production in granuloma faciale (eosinophilicum): role of clonally expanded skin-specific CD4+ cells. Br J Dermatol 2005(153): 454-457. https://doi.org/10.1111/j.1365-2133.2005.06752.x

128. Cesinaro AM, Lonardi S, Facchetti F (2013) Granuloma faciale: a cutaneous lesion sharing features with IgG4-associated sclerosing diseases. Am J Surg Pathol 37:66-73. https://doi.org/10.1097/ PAS.0b013e318271 efd0

129. Buder K, Ruppert S, Trautmann A, Bröcker EB, Goebeler M, Kerstan A (2014) Angiolymphoid hyperplasia with eosinophilia and Kimura's disease - a clinical and histopathological comparison. J Dtsch Dermatol Ges 12:224-228. https://doi.org/10.1111/ ddg.12257_suppl

130. Kimura Y, Pawankar R, Aoki M, Niimi Y, Kawana S (2002) Mast cells and $\mathrm{T}$ cells in Kimura's disease express increased levels of interleukin-4, interleukin-5, eotaxin and RANTES. Clin Exp Allergy 32:1787-1793. https://doi.org/10.1046/j.1365-2222. 2002.01552.x

131. Galdiero MR, Varricchi G, Seaf M, Marone G, Levi-Schaffer F, Marone G (2017) Bidirectional mast cell-eosinophil interactions in inflammatory disorders and cancer. Front Med (Lausanne) 4: 103. https://doi.org/10.3389/fmed.2017.00103

132. Davis MD, Perniciaro C, Dahl PR, Randle HW, McEvoy MT, Leiferman KM (1998) Exaggerated arthropod-bite lesions in patients with chronic lymphocytic leukemia: a clinical, histopathologic, and immunopathologic study of eight patients. J Am Acad Dermatol 39:27-35. https://doi.org/10.1016/s0190-9622(98) 70398-6

133. Chassine AF, Dadban A, Charfi S, Chaby G, Royer B, Damaj G, Chatelain D, Lok C (2010) Eosinophilic dermatosis associated with hematological disorders: A clinical, histopathological and immunohistochemical study of six observations. Ann Dermatol Venereol 137:181-188. https://doi.org/10.1016/j.annder.2010.02. 001

134. Meiss F, Technau-Hafsi K, Kern JS, May AM (2019) Eosinophilic dermatosis of hematologic malignancy: correlation of molecular characteristics of skin lesions and extracutaneous manifestations of hematologic malignancy. J Cutan Pathol 46:175-181. https:// doi.org/10.1111/cup.13389

135. Martinez-Cabriales SA, Walsh S, Sade S, Shear NH (2020) Lymphomatoid papulosis: an update and review. J Eur Acad Dermatol Venereol 34:59-73. https://doi.org/10.1111/jdv.15931
136. Kitano K, Ichikawa N, Shimodaira S, Ito T, Ishida F, Kiyosawa K (1997) Eosinophilia associated with clonal T-cell proliferation. Leuk Lymphoma 27:335-342. https://doi.org/10.3109/ 10428199709059688

137. Kusam S, Toney LM, Sato H, Dent AL (2003) Inhibition of Th2 differentiation and GATA-3 expression by BCL-6. J Immunol 170:2435-2441. https://doi.org/10.4049/jimmunol.170.5.2435

138. Jundt F, Anagnostopoulos I, Bommert K, Emmerich F, Müller G, Foss HD, Royer HD, Stein H, Dörken B (1999) Hodgkin/ReedSternberg cells induce fibroblasts to secrete eotaxin, a potent chemoattractant for T cells and eosinophils. Blood. 94:2065-2071

139. Gebhardt C, Sevko A, Jiang H, Lichtenberger R, Reith M, Tarnanidis K, Holland-Letz T, Umansky L, Beckhove P, Sucker A, Schadendorf D, Utikal J, Umansky V (2015) Myeloid cells and related chronic inflammatory factors as novel predictive markers in melanoma treatment with ipilimumab. Clin Cancer Res 21: 5453-5459. https://doi.org/10.1158/1078-0432.CCR-15-0676

140. Khoury P, Grayson PC, Klion AD (2014) Eosinophils in vasculitis: characteristics and roles in pathogenesis. Nat Rev Rheumatol 10:474-483. https://doi.org/10.1038/nrrheum.2014.98

141. Wechsler ME, Akuthota P, Jayne D, Khoury P, Klion A, Langford CA, Merkel PA, Moosig F, Specks U, Cid MC, Luqmani R, Brown J, Mallett S, Philipson R, Yancey SW, Steinfeld J, Weller PF, Gleich GJ, EGPA Mepolizumab Study Team (2017) Mepolizumab or placebo for eosinophilic granulomatosis with polyangiitis. N Engl J Med 376:1921-1932. https://doi.org/10. 1056/NEJMoa1702079

142. Guntur VP, Manka LA, Denson JL, Dunn RM, Dollin YT, Gill M, Kolakowski C, Strand MJ, Wechsler ME (2021) Benralizumab as a steroid-sparing treatment option in eosinophilic granulomatosis with polyangiitis. J Allergy Clin Immunol Pract 9:1186-1193.e1. https://doi.org/10.1016/j.jaip.2020.09.054

143. Manka LA, Guntur VP, Denson JL, Dunn RM, Dollin YT, Strand MJ, Wechsler ME (2021) Efficacy and safety of reslizumab in the treatment of eosinophilic granulomatosis with polyangiitis. Ann Allergy Asthma Immunol S1081-1206(21)00097-1. https://doi. org/10.1016/j.anai.2021.01.035

144. Ihn H (2019) Eosinophilic fasciitis: from pathophysiology to treatment. Allergol Int 68:437-439. https://doi.org/10.1016/j.alit.2019. 03.001

145. Pinal-Fernandez I, Selva-O' Callaghan A, Grau JM (2014) Diagnosis and classification of eosinophilic fasciitis. Autoimmun Rev 13:379-382. https://doi.org/10.1016/j.autrev. 2014.01.019

146. Ferreli C, Gasparini G, Parodi A, Cozzani E, Rongioletti F, Atzori L (2017) Cutaneous manifestations of scleroderma and scleroderma-like disorders: a comprehensive review. Clin Rev Allergy Immunol 53:306-336. https://doi.org/10.1007/s12016017-8625-4

147. Kinoshita M, Ogawa Y, Onaka M, Shimada S, Kawamura T (2021) Mepolizumab-responsive Kimura disease. J Allergy Clin Immunol Pract S2213-2198(21)00292-0. https://doi.org/10.1016/ j.jaip.2021.02.049

148. Magerl M, Terhorst D, Metz M, Altrichter S, Zuberbier T, Maurer M, Bergmann KC (2018) Benefit of mepolizumab treatment in a patient with chronic spontaneous urticaria. J Dtsch Dermatol Ges 16:476-477. https://doi.org/10.1111/ddg.13481_g

149. Maurer M, Altrichter S, Metz M, Zuberbier T, Church MK, Bergmann KC (2018) Benefit from reslizumab treatment in a patient with chronic spontaneous urticaria and cold urticaria. $\mathrm{J}$ Eur Acad Dermatol Venereol 32:e112-e113. https://doi.org/10. 1111/jdv.14594

150. Youngblood BA, Leung J, Falahati R, Williams J, Schanin J, Brock EC, Singh B, Chang AT, O'Sullivan JA, Schleimer RP, Tomasevic N, Bebbington CR, Bochner BS (2020) Discovery, 
function, and therapeutic targeting of Siglec-8. Cells. 10:19. https://doi.org/10.3390/cells10010019

151. Beck LA, Thaçi D, Hamilton JD, Graham NM, Bieber T, Rocklin R, Ming JE, Ren H, Kao R, Simpson E, Ardeleanu M, Weinstein SP, Pirozzi G, Guttman-Yassky E, Suárez-Fariñas M, Hager MD, Stahl N, Yancopoulos GD, Radin AR (2014) Dupilumab treatment in adults with moderate-to-severe atopic dermatitis. N Engl J Med 371:130-139. https://doi.org/10.1056/NEJMoa1314768

152. Abdat R, Waldman RA, de Bedout V, Czernik A, Mcleod M, King B, Gordon S, Ahmed R, Nichols A, Rothe M, Rosmarin D (2020 Jul) Dupilumab as a novel therapy for bullous pemphigoid: a multicenter case series. J Am Acad Dermatol 83(1):46-52. https://doi.org/10.1016/j.jaad.2020.01.089

153. Goyal A, Lofgreen S, Mariash E, Bershow A, Gaddis KJ (2020) Targeted inhibition of IL-4/13 with dupilumab is an effective treatment for eosinophilic dermatosis of hematologic malignancy. Dermatol Ther 33:e13725. https://doi.org/10.1111/dth.13725

154. Jin A, Pousti BT, Savage KT, Mollanazar NK, Lee JB, Hsu S (2019) Eosinophilic dermatosis of hematologic malignancy responding to dupilumab in a patient with chronic lymphocytic leukemia. JAAD Case Rep 5:815-817. https://doi.org/10.1016/j. jdcr.2019.07.026

155. Wollenberg A, Howell MD, Guttman-Yassky E, Silverberg JI, Kell C, Ranade K, Moate R, van der Merwe R (2019 Jan) Treatment of atopic dermatitis with tralokinumab, an anti-IL-13 mAb. J Allergy Clin Immunol 143(1):135-141. https://doi.org/10. 1016/j.jaci.2018.05.029

156. Simpson EL, Flohr C, Eichenfield LF, Bieber T, Sofen H, Taïeb A, Owen R, Putnam W, Castro M, DeBusk K, Lin CY, Voulgari A, Yen K, Omachi TA (2018) Efficacy and safety of lebrikizumab (an anti-IL-13 monoclonal antibody) in adults with moderate-to- severe atopic dermatitis inadequately controlled by topical corticosteroids: a randomized, placebo-controlled phase II trial (TREBLE). J Am Acad Dermatol 78(5):863-871.e11. https:// doi.org/10.1016/j.jaad.2018.01.017

157. King B, Lee AI, Choi J (2017) Treatment of hypereosinophilic syndrome with cutaneous involvement with the JAK inhibitors tofacitinib and ruxolitinib. J Invest Dermatol 137:951-995. https://doi.org/10.1016/j.jid.2016.10.044

158. Guttman-Yassky E, Silverberg JI, Nemoto O, Forman SB, Wilke A, Prescilla R, de la Peña A, Nunes FP, Janes J, Gamalo M, Donley D, Paik J, DeLozier AM, Nickoloff BJ, Simpson EL (2019) Baricitinib in adult patients with moderate-to-severe atopic dermatitis: a phase 2 parallel, double-blinded, randomized placebo-controlled multiple-dose study. J Am Acad Dermatol 80:913-921.e9. https://doi.org/10.1016/j.jaad.2018.01.018

159. Guttman-Yassky E, Thaçi D, Pangan AL, Hong HC, Papp KA, Reich K, Beck LA, Mohamed MF, Othman AA, Anderson JK, Gu Y, Teixeira HD, Silverberg JI (2020) Upadacitinib in adults with moderate to severe atopic dermatitis: 16-week results from a randomized, placebo-controlled trial. J Allergy Clin Immunol 145: 877-884. https://doi.org/10.1016/j.jaci.2019.11.025

160. Gooderham MJ, Forman SB, Bissonnette R, Beebe JS, Zhang W, Banfield C, Zhu L, Papacharalambous J, Vincent MS, Peeva E (2019) Efficacy and safety of oral janus kinase 1 inhibitor abrocitinib for patients with atopic dermatitis: a phase 2 randomized clinical trial. JAMA Dermatol 155:1371-1379. https://doi. org/10.1001/jamadermatol.2019.2855

Publisher's note Springer Nature remains neutral with regard to jurisdictional claims in published maps and institutional affiliations. 